\title{
The control of cardiac ventricular excitability by autonomic pathways
}

\author{
Malcolm Finlay, Stephen C Harmer and Andrew Tinker*
}

The Heart Centre, William Harvey Research Institute, Barts and the London School of Medicine and Dentistry, Charterhouse Square, London, EC1M6BQ, UK

* Author for correspondence. Email: a.tinker@qmul.ac.uk Tel: 02078825783

Short Title: Regulation of ventricular excitability

Word count: 14,705 


\begin{abstract}
Central to the genesis of ventricular cardiac arrhythmia are variations in determinants of excitability. These involve individual ionic channels and transporters in cardiac myocytes but also tissue factors such as variable conduction of the excitation wave, fibrosis and source-sink mismatch. It is also known that in certain diseases and particularly the channelopathies critical events occur with specific stressors. For example, in hereditary long QT syndrome due to mutations in KCNQ1 arrhythmic episodes are provoked by exercise and in particular swimming. Thus not only is the static substrate important but also how this is modified by dynamic signalling events associated with common physiological responses. In this review, we examine the regulation of ventricular excitability by signalling pathways from a cellular and tissue perspective in an effort to identify key processes, effectors and potential therapeutic approaches. We specifically focus on the autonomic nervous system and related signalling pathways.
\end{abstract}

Keywords: cardiac ventricle, cardiac arrhythmia, autonomic nervous system, ion channels, excitability, conduction velocity 


\section{Table of Contents}

Introduction: page 5

Ion channels and transporters determining ventricular excitability: page 5

The major hormonal systems impinging on ventricular excitability: page 8

Regulation of ventricular ion channels: page 12

Regulation of ventricular excitability at the tissue level: page 18

Clinical perspective: page 25

Summary and Outlook: page 30

Figure legends: page 32

References: page 34

\section{Abbreviations}

Action Potential: AP

Action Potential Duration: APD

Catecholaminergic Polymorphic Ventricular Tachycardia: CPVT

Calcium calmodulin dependent kinase II: CamKII

Effective Refractory Period: ERP

Implantable Cardiac Defibrillator: ICD

Ion channel currents: " $\mathrm{I}_{\mathrm{x}}$ " where $\mathrm{x}$ is a specific identifier for the current

Inositol trisphosphate: $\mathrm{IP}_{3}$

Long QT syndrome: LQTS

L-type calcium currents: LTCC

Nitric Oxide: NO

Nitric Oxide Synthase: NOS

Protein kinase A: PKA

Protein Kinase C: PKC 
Sinoatrial and atrioventricular respectively: SA and AV 


\section{Introduction}

An array of ion channels and transporters determine the excitable properties of the heart. This can be assessed in a variety of ways from single cell studies using patch clamping and imaging, field potentials measured using electrode arrays from the surface of cardiac tissue through to measurement in the whole animal using electrocardiography. This normal electrical activity of the heart can become disordered and lead to cardiac arrhythmia. In the ventricle this is particularly critical as the activity can become sufficiently chaotic to lead to sudden cardiac death. The electrical activity of the heart can be modulated through hormonal signalling pathways particularly the two arms of the autonomic nervous system. For example, it is known that exercise can provoke arrhythmic events in hereditary channelopathies and that common cardiac pathologies such as heart failure can lead to a sympathovagal imbalance and may further enhance the predisposition to arrhythmia.

There has been a substantial body of important work over the last fifty years dissecting out the regulation of individual ion channels and currents in cardiac ventricular myocytes. These studies have often occurred in single cells and the significance of the phenomena is not always clear for regulation in the whole heart. There has been less work in the whole heart and in man. In this review we consider how hormonal systems can modulate ventricular cardiac excitability. Specifically, we focus on processes in which there is a clear consensus of experimental evidence in single cells and consider how this links with tissue electrophysiology and arrhythmogenesis.

\section{Ion channels and transporters determining ventricular excitability}

A convenient cellular starting point is the ventricular cardiac action potential as illustrated in Figure 1 together with how currents might be potentially modulated by increased beta adrenergic drive. We will briefly overview this area to set the scene but it is well known and has been reviewed before (Roden et al., 2002; Davis et al., 2011; Schmitt et al., 2014). We focus on the human action 
potential. It should be appreciated there are considerable species differences particularly between rodents and large mammals (Davis et al., 2011; Munroe and Tinker, 2015).

Sodium channels: The fast upstroke (phase 0) is mediated by rapid opening and subsequent inactivation of sodium channels. The pore forming cardiac isoform is SCN5A and there are a variety of beta isoforms that modulate the properties of the alpha subunit: at least two are present in the ventricle (Catterall, 2012). The alpha subunit consists of four groups of six transmembrane domains with voltage sensing and activation mediated by the S4 segment and inactivation by residues in the III-IV linker. It is possible other isoforms are present in the ventricle particularly in the t-tubular network (Westenbroek et al., 2013). Cardiac sodium channels are characteristically much less sensitive to tetrodotoxin than those present in central and peripheral nerves. It is also worth noting that sodium channels even when inactivated continue to pass a small persistent inward current (Saint, 2008).

Transient outward $K+$ current $\left(I_{t o}\right)$ : There is transient repolarisation and notching of the action potential that is mediated by a group of potassium currents that rapidly activate and inactivate known as $\mathrm{I}_{\text {to }}$ ("transient outward"). $\mathrm{I}_{\text {to, } \mathrm{f}}$ is a fast transient $\mathrm{K}^{+}$current constituted of a complex of $\mathrm{K}_{\mathrm{v}} 4.2$ and 4.3 and the beta subunit KChip2 (Dixon et al., 1996; An et al., 2000; Oudit et al., 2001). $\mathrm{I}_{\mathrm{to}, \mathrm{s}}$ has slower kinetics, a more limited distribution probably only being present in myocytes from the ventricular septum and is likely constituted of $\mathrm{K}_{\mathrm{v}} 1.4$ (London et al., 1998).

Calcium currents: Two major types of voltage-gated calcium channels are recognised in cardiac tissues namely L-type ("long-lasting") and T-type ("transient/tiny"). The L-type channel (LTCC) in the ventricle, is largely formed by $\mathrm{Ca}_{\mathrm{v}} 1.2$ and can combine with ancillary subunits namely $\alpha_{2} \delta, \beta$ and $\gamma$ which increase alpha subunit expression, current density and alter the dynamics of activation/inactivation (Roden et al., 2002).

$K^{+}$currents in terminal repolarisation: The potassium currents involved in terminal repolarisation are $I_{K r}$ and $I_{K s}$. $I_{K r}$ is a rapidly activating and inwardly rectifying $\mathrm{K}^{+}$current that is formed by the complex of hERG (human ether-a-go-go related gene) together with perhaps a $\beta$ subunit of the 
KCNE family (Trudeau et al., 1995; Abbott et al., 1999). $\mathrm{I}_{\mathrm{Ks}}$ is characteristically very slowly activating and the study of patients with the hereditary long QT syndrome revealed that the $\mathrm{I}_{\mathrm{Ks}}$ channel complex is a tetramer of KCNQ1 (Kv7.1) $\alpha$-subunits together with the $\beta$ subunit KCNE1 (Barhanin et al., 1996; Sanguinetti et al., 1996).

$I_{K 1}$ : $\mathrm{I}_{\mathrm{K} 1}$ is a strong inwardly rectifying $\mathrm{K}^{+}$current present in ventricular cells. The window of outward current largely determines the resting membrane potential and it is also important in late repolarisation. $\mathrm{K}_{\mathrm{ir}} 2.1$ is probably the major contributor to the current but other Kir2.0 isoforms cannot be totally excluded (Zaritsky et al., 2001; Liu et al., 2001).

Other currents: In many cells including cardiac myocytes there is a leak $\mathrm{K}^{+}$conductance even after pharmacological inhibition of the known $\mathrm{K}^{+}$currents. These currents seem to correspond to a family of channels encoded by twin $\mid$ two pore subunits assembling as a dimer (Lesage and Lazdunski, 2000). The significance of these channels for cardiac ventricular electrophysiology is relatively unexplored but they have a number of interesting properties (Putzke et al., 2007).

ATP-sensitive $\mathrm{K}^{+}$channels ( $\mathrm{I}_{\mathrm{KATP}}$ ) respond to the metabolic product (ATP:MgADP ratio) and open as cellular energy provision becomes compromised. The standard view is that the ventricular channel is an octameric complex made up of a pore-forming $\mathrm{K}_{\mathrm{ir}} 6.2$ and the SUR2A sulphonylurea receptor subunit (Tinker et al., 2014).

The $\mathrm{Na}^{+}-\mathrm{Ca}^{2+}$ exchanger is important for cellular extrusion of calcium from the myocyte at the end of the action potential. Importantly the transport is electrogenic with three sodium ions entering for a single $\mathrm{Ca}^{2+}$ ion i.e. a net inward current. It is important as pathological often diastolic calcium release events from the sarcoplasmic reticulum can lead to inappropriate and proarrhythmic sarcolemmal depolarisations. NCX1 is the isoform present in ventricular myocytes (Nicoll et al., 2007).

\section{The major neuro-hormonal systems impinging on ventricular excitability}

In the following section we do not provide a comprehensive list of hormonal systems but 
rather try to focus on areas of potential scientific interest and clinical significance.

Innervation of the heart: The heart is densely innervated by nerves and plexi of the autonomic nervous system and contains neurones expressing markers of adrenergic, cholinergic and nitrergic origin. In addition this innervation shows regional variation and single nerves may on occasion express more than one transmitter pathway. For example in the rabbit, four chemical subtypes were observed within ventricular ganglia: cells were positive for choline acetyltransferase, neuronal nitric oxide synthase (nNOS), and positive for both choline acetyltransferaselneuronal nitric oxide synthase and for choline acetyltransferaseltyrosine hydroxylase (Pauziene et al., 2016). There were also potentially sensory neurofilaments positive for both calcitonin gene-related peptide and substance $\mathrm{P}$ that innervated the ventricular endo and epicardium. Though adrenergic neurofilaments predominated there were substantial regional differences in the myocardium and endo and epicardium (Pauziene et al., 2016). It should be emphasised that there is now considerable evidence for interaction of sympathetic and vagal efferent fibres and sensory fibres and interneurons within intracardiac ganglia and extra-cardiac intrathoracic ganglia leading to the possibility of quite complex reflex behaviours at this level (Armour, 2008).

Sympathetic nervous system: Ultimately efferent sympathetic nerve fibres innervating the heart release noradrenaline and together with adrenaline released from the adrenal medulla these act on adrenoreceptors to modulate ventricular excitability. $\beta$-adrenoceptors present in the sarcolemma are one of the main effectors and are an archetypal seven-helix G-protein coupled receptor. They comprise $\beta 1, \beta 2$ and perhaps $\beta 3$ subclasses and in the normal human heart $\beta 1$ adrenoreceptors predominate with the ratio to $\beta 2$ being approximately 4:1 (Brodde, 1991). However in heart failure the expression of the $\beta 1$ receptor falls whilst $\beta 2$ levels remain the same.

The cellular pathways entrained by activation of $\beta 1$ and $\beta 2$ receptors are different. $\beta 1$ adrenoreceptors couple exclusively to the stimulatory G-protein, $\mathrm{G}_{\mathrm{s}}$, and via adenylate cyclase to increases in cAMP and activation of protein kinase A (PKA) (Xiao et al., 2006). Phosphorylation of key proteins such as the LTCC and phospholamban results in the positive inotropic and lusitropic 
effects (see below). Increased cAMP can also lead to direct activation of a guanine nucleotide exchange factor known as EPAC (exchange proteins directly activated by cAMP) for the small Gprotein Rap1. Rap1 is a member of the ras family of small G-protein and activates signaling pathways involved in cell adhesion and junction formation (Lezoualc'h et al., 2016). Investigators are actively pursuing regulation of membrane proteins by EPACs but there is as yet no clear consensus on their potential role. Sustained stimulation of $\beta 1$ adrenoreceptors also activates calcium-calmodulin dependent kinase II increasing contractile function but also leading to myocyte death (Wang et al., 2004a). Signalling is more complex through $\beta 2$ adrenoreceptors. These receptors also couple to $\mathrm{G}_{\mathrm{s}} \backslash$ adenylate cyclase $\backslash \mathrm{c} A M P \backslash P K A$ and can increase cAMP however these effects are less pronounced and there is modest positive inotropism. However it has become clear that $\beta 2$ adrenoreceptors also signal through inhibitory G-proteins $\left(G_{i}\right)$ and this accounts for the attenuation of cAMP mediated signaling compared to activation of $\beta 1$ adrenoreceptors (Xiao et al., 1999; Xiao et al., 2003). The recruitment of $G_{i}$ signalling by the $\beta 2$ adrenoreceptor also activates pathways promoting myocyte survival such as the phosphatidylinositide 3-kinases (Chesley et al., 2000). It also seems that mechanisms traditionally associated with $\beta$-receptor desensitization and internalization, namely G-protein coupled receptor kinases and $\beta$-arrestin binding, might also initiate novel protective signaling pathways (Lefkowitz and Shenoy, 2005; Shenoy et al., 2006; Shukla et al., 2014). This seems to be a particular feature of the $\beta 2$ adrenoreceptor (Kahsai et al., 2011). Furthermore, specific agonists can entrain to varying degrees each of these three separate signalling modes; a process known as protean agonism (Wisler et al., 2014). This may be relevant for the effects of $\beta$-blockers such as carvedilol (Wisler et al., 2007). Another factor in the differential signaling between $\beta 1$ and $\beta 2$ receptors is likely to be subcellular distribution and assembly into protein complexes. The $\beta 1$ receptor is widely distributed within the sarcolemmal membrane whilst the $\beta 2$ is confined to the t-tubule. Intriguingly this distribution changes in heart failure (Nikolaev et al., 2010). 
Cardiac muscle also contains $\alpha 1$ ( $\alpha 1 \mathrm{a}$ and $\alpha 1 \mathrm{~b})$ adrenergic receptors and activation leads to a positive inotropic effect and to myocyte hypertrophy (Endoh, 1996). The $\alpha 1$ receptors couple to $\mathrm{G}_{\mathrm{q} \backslash 11}$ and the inotropic response is related to the activation of protein kinase $\mathrm{C}$ (PKC) (Endoh et al., 1993).

Parasympathetic innervation of the ventricle: Parasympathetic efferent nerves are well known to innervate the SA and AV nodes and the atria. However a consensus on vagal innervation of the ventricles is less clear. Indeed the textbook view posits that it is sparse and of little functional significance. However it is clear that choline acetyltransferase-positive nerve fibres innervate the ventricle and the acetylcholinesterase enzyme and muscarinic receptors are present (Coote, 2013). Furthermore, there are functional data showing that vagus nerve stimulation can decrease the force of ventricular contraction independent of heart rate changes (Xenopoulos and Applegate, 1994; Lewis et al., 2001).

At the cellular level the release of acetylcholine has the potential to act on a range of metabotropic muscarinic G-protein coupled receptors (M1 through to M5) (Caulfield and Birdsall, 1998). The predominant cardiac and ventricular isoforms isoform is M2 and this couples to inhibitory G-proteins antagonising cAMP mediated signalling (Peralta et al., 1987; Peralta et al., 1988; Caulfield and Birdsall, 1998). However there are indications that other family members might be present in particular M1 and M3 receptors (Wang et al., 2004b). The transcript and protein for the M3 receptor are expressed in the ventricle and various pharmacological responses consistent with the expression of these isoforms can be evoked (Wang et al., 2004b). The M1 and M3 muscarinic receptors couple to the $\mathrm{G}_{\mathrm{q} \backslash 11}$ family of $\mathrm{G}$-protein and lead to activation of phospholipase C. This in turn leads to the generation of diacylglycerol and $\mathrm{IP}_{3}$ which in turn activate PKC and release calcium from intracellular stores (Peralta et al., 1988; Berridge, 2009; Tinker et al., 2016). In the ventricle, the $\mathrm{IP}_{3}$ receptor is largely involved in nuclear calcium signalling and hypertrophy with little effect on calcium transients associated with excitation-contraction coupling (Nakayama et al., 2010). 
Other receptor pathways and orphan GPCRs: A wide range of other receptor systems are expressed in cardiac ventricles. Their effects can be broadly understood by knowing their G-protein coupling profile though there are significant nuances in the cell signalling. For example, histamine (H2), vasoactive intestinal polypeptide and the prostacyclin receptors are expressed in ventricular cardiac myocytes and couple to $\mathrm{G}_{\mathrm{s}}$. Thus agonist activation of these pathways is positively inotropic (Levi et al., 1975; Christophe et al., 1984; Alloatti et al., 1991). In addition to the M2 muscarinic receptor there are receptors for somatostatin and sphingosine-1-phosphate that couple to inhibitory Gproteins (Bell et al., 2008; Ochi et al., 2006). GPCRs for endothelin (ET-A) and angiotensin II (AT1) are present in ventricular cells and these couple to $G_{q \backslash 11}$ leading to modest positively inotropic effects and cardiac hypertrophy (Pieske et al., 1999; Regitz-Zagrosek et al., 1995; Sugden and Clerk, 1998). What is even more intriguing is the presence of orphan G-protein coupled receptors. Regard and colleagues used a systematic approach with real-time quantitative PCR to profile the expression of all non-chemosensory GPCRs in forty one tissues (Regard et al., 2008). They observed high level expression of a number of orphan GPCRs in murine atria and ventricles. That these might have novel physiological functions was supported by the clustering of known GPCRs into the same hierarchical families according to tissue expression.

Nitric oxide: Nitric oxide is synthesised from L-arginine by nitric oxide synthases (NOS). There are three NOS proteins: an isoform present in the endothelium (eNOS), one present in neuronal tissues (nNOS) and one that is expressed during inflammation (iNOS) (Sessa et al., 1992; Sessa, 1994). NOS are also present in cardiac myocytes with eNOS located in the plasma membrane probably in caveolae and nNOS located in the sarcoplasmic reticulum and in association with syntrophin and a membrane calcium pump (Feron et al., 1996; Xu et al., 1999; Williams et al., 2006). Syntrophins are part of the dystrophin complex. Nitric oxide, which is freely diffusible, could also be produced from endothelial cells and neurones in addition to myocytes. Nitric oxide activates guanylate cyclase leading to cGMP production and the activation of protein kinase G (Follmann et al., 2013). Nitric oxide can also directly modify proteins through nitrosylation with accompanying changes in 
function (Simon et al., 1996; Foster et al., 2009; Irie et al., 2015). Nitric oxide is produced constitutively and this may be increased in specific physiological or pathological states (Simon et al., 2014).

Calcium calmodulin dependent kinase II: The major isoform of calcium calmodulin dependent kinase II in the heart is CamKIII. Activation of this serinelthreonine kinase is dependent on the binding of calcium-calmodulin. Physiological activation occurs with repetitive high frequency calcium signalling and integrates the oscillatory signal. Furthermore, CamKII activation is associated with autophosphorylation and this seems to endow the system with memory even after cessation of the initial high frequency $\mathrm{Ca}^{2+}$ train (De and Schulman, 1998). In general, it is thought that activated CamKII in the heart helps to reinforce positive inotropic signalling and this is reflected in the potential phosphorylation of a large number of ion channels and proteins involved in calcium handling (see below). However when prolonged this signalling becomes potentially pathological (Erickson, 2014).

\section{Regulation of ventricular ion channels}

L-type calcium channels: The LTCC is activated by $\beta$-adrenergic regulation through PKA with at least a doubling of the current (Reuter, 1967; Tsien et al., 1986). PKA is thought to phosphorylate CACNA1C at S1928 with perhaps contribution from other phosphorylation sites on the beta2a subunit (Kamp and Hell, 2000; Hulme et al., 2006). Graded increases in calcium entry after $\beta$ adrenergic stimulation are necessary for increases in calcium release from the sarcoplasmic reticulum and positive inotropy (Fabiato, 1985). The activation seems to be facilitated by the anchoring of PKA at the membrane via a PKA anchoring protein such as AKAP5 (Fraser et al., 1998; Diviani et al., 2015). Indeed, AKAP5 can also complex the $\beta 1$ adrenergic receptor, calcineurin, adenylate cyclases and PKC (Diviani et al., 2015).

In the resting state activation of receptors coupling to inhibitory G-proteins such as M2 muscarinic and A1 adenosine receptor does not have an effect on the LTCC. However if the current 
is activated through the $\beta$-adrenergic system then stimulation of these receptor systems can antagonise the effect probably via $\mathrm{G}_{\alpha \mathrm{i} 2}$ (Belardinelli and Isenberg, 1983; Chen et al., 2001). Agonist activation of $\mathrm{G}_{\mathrm{q} \backslash 11}$ coupled receptors do not seem to have consistent and well agreed effects on the LTCC. Nitric oxide also seems to mediate an inhibitory effect on LTCC in ventricular cardiomyocytes. Thus inhibition of nNOS using drugs or in knockout mice led to an increase in current (Gallo et al., 1998; Gallo et al., 2001; Sears et al., 2003). Nitric oxide modulates LTCCs both via protein kinase $\mathrm{G}$ phosphorylation and direct channel nitrosylation (Mery et al., 1991; Hu et al., 1997).

Intracellular calcium has complex effects on the properties of LTCCs. It is responsible for calcium dependent inactivation which in physiological conditions results from calcium release from the SR (Kass and Sanguinetti, 1984; Sipido et al., 1995). This process limits calcium entry and thus abnormal action potential prolongation. In contrast, LTCC amplitude is rate dependent and increases with increasing frequency of voltage pulses from physiological resting membrane potentials. This process is $\mathrm{Ca}^{2+}$ dependent, for example it does not occur if $\mathrm{Ba}^{2+}$ is the charge carrier, and is known as calcium dependent facilitation (Hryshko and Bers, 1990; Bers and Morotti, 2014). This effect is probably responsible for the positive Bowditch staircase which occurs in most species except rodents (Boyett and Fedida, 1988; Bers and Morotti, 2014). The key mediator in this response appears to CamKII (Anderson et al., 1994). Studies after heterologous expression of the molecular components of the LTCC strongly support the idea that CamKII directly phosphorylates the $\alpha$ subunit and perhaps also the $\beta 2$ subunit (Hudmon et al., 2005; Lee et al., 2006; Grueter et al., 2006). Indeed, in a mouse with knockin mutation of putative phosphorylation sites on the $\alpha$ subunit there was impaired calcium dependent LTCC facilitation (Blaich et al., 2010).

Other aspects of calcium signalling: Abnormal membrane depolarisations that occur in diastole known as delayed afterdepolarisations (DADs) may be dependent on intracellular calcium signalling events. Spontaneous and abnormal release of calcium from the SR leads to activation of the $\mathrm{Na} \backslash \mathrm{Ca}$ exchanger and a depolarising inward current. For example in mice that lack FKBP12 
activity of RyR2 is increased resulting in spontaneous calcium release during diastole and DADs (Wehrens et al., 2003). Furthermore in the rare arrhythmic syndrome, catecholaminergic polymorphic ventricular tachycardia (CPVT), there are mutations in RyR2 that lead to increased activity (Priori et al., 2001). Cell signalling pathways seem to have a critical place in modulating SR calcium load through the SR calcium pump (SERC2A regulated by phospholamban) and the cardiac ryanodine receptor (RyR2). Phospholamban is a small integral membrane protein that acts to inhibit SERC2A activity unless phosphorylated (Fujii et al., 1991). Thus, protein kinase A can phosphorylate phospholamban at serine residue 16 leading to increased SERCA2A activity resulting in accelerated relaxation and increased calcium uptake into the SR (Kranias and Solaro, 1982; Li et al., 2000). There are data supporting increases of RyR2 activity mediated by direct phosphorylation of the protein at serine 2808 (Shan et al., 2010). It is proposed that this phosphorylation event destabilises the interaction with FKBP12 (Wehrens et al., 2006) and is responsible for increased SR calcium release via the $\beta$-adrenergic receptor. However this is controversial with a number of investigators proposing that CamKII phosphorylation is the critical regulator of RyR2 channel activity, on residues S2808, S2814, S2820, in these situations (reviewed in (Camors and Valdivia, 2014)). Interestingly CamKII can also phosphorylate phospholamban at T17 leading to a reversal of the inhibition of the calcium pump SERCA2A and increased loading of the SR with calcium (Mattiazzi and Kranias, 2014). Nitric oxide might also modulate RyR2 through direct nitrosylation although there isn't a consensus on the exact details and functional consequences (Simon et al., 2014).

The sympathetic nervous system is key to promoting increased inotropy and lusitropy. However increased activity may also be pathological and proarrhythmic particularly if the stimulus is prolonged or excessive or on the background of a pathological substrate as in catecholaminergic polymorphic ventricular tachycardia (CPVT) or heart failure (Camors and Valdivia, 2014). In particular, the increased loading of the SR with $\mathrm{Ca}^{2+}$ through phospholamban disinhibition and increased entry via the LTCC might lead to abnormal diastolic calcium release promoting delayed 
after-depolarisations. Initially this would be entrained by protein kinase A activation but as the signal became sustained CamKII would increase in importance. Some of the antiarrhythmic effects of vagal nerve activation may occur because they broadly antagonise such events.

Potassium channels: $I_{t o}$ : Both $\alpha$ and to a lesser extent $\beta$-adrenergic signalling have been reported to result in a reduction in $\mathrm{I}_{\text {to }}$ (Apkon and Nerbonne, 1988; Shimoni and Banno, 1993; van der Heyden et al., 2006). It is also likely that the current reducing effects initiated by $\alpha$-adrenergic signalling override any competing effects caused by the stimulation of $\beta$-adrenergic signalling (van der Heyden et al., 2006). Adrenergic stimulation has been linked to the activation of PKA and PKC and subsequent phosphorylation of the channel (van der Heyden et al., 2006). In a number of disease states, such as heart failure, diabetes, ischaemia and infarction, reductions in $\mathrm{I}_{\text {to }}$ density and respective subunit expression have been reported and at least a component of this is thought to be due to aberrant adrenergic signalling (van der Heyden et al., 2006). The actions of nitric oxide and angiotensin II on the properties of the $\mathrm{I}_{\mathrm{to}}$ have also been studied and both appear to reduce current density (Gomez et al., 2008; Caballero et al., 2004).

$I_{K s}: \beta$-adrenergic stimulation leads to increased $\mathrm{I}_{\mathrm{Ks}}$ and this augmentation likely plays an important role in APD shortening at higher heart rates. Since the discovery that $\mathrm{I}_{\mathrm{K}}$ is enhanced by adrenergic stimulation (Bennett and Begenisich, 1987) the mechanisms underlying this augmentation have been extensively studied. With the separation of $\mathrm{I}_{\mathrm{K}}$ into two currents (Sanguinetti and Jurkiewicz, 1990) it became clear that $I_{K s}$ was the $\beta$-adrenergic sensitive component (Sanguinetti et al., 1991). Extensive characterisation of $\beta$-adrenergic stimulation on $\mathrm{I}_{\mathrm{Ks}}$ has led to the elucidation of a detailed and intricate mechanism of action. Briefly, $\beta$-adrenergic signalling leads to PKA activation and results in direct channel phosphorylation of the N-terminal residue(s) S27 (and potentially S92) (Marx et al., 2002). The augmentation of $\mathrm{I}_{\mathrm{Ks}}$ requires the association of KCNQ1 with KCNE1. In addition it is also dependent on the presence of a protein kinase A anchoring protein (AKAP) yotiao\AKAP9 and also a direct interaction with the microtubule network (Marx et al., 2002; Kurokawa et al., 2003; Nicolas et al., 2008). A phosphodiesterase (PDE4D3) may also form part of 
this channel complex (Terrenoire et al., 2009) and to mediate the full effects on current augmentation yotiao\AKAP9 also needs to be phosphorylated by PKA (Chen et al., 2005; Terrenoire et al., 2009). The effects of $\mathrm{G}_{\mathrm{q}}$-coupled receptor stimulation on $\mathrm{I}_{\mathrm{Ks}}$ in cardiac myocytes have not been extensively characterised although Daleau et al., have reported that angiotensin II can decrease $\mathrm{I}_{\mathrm{Ks}}$ density in guinea pig myocytes (Daleau and Turgeon, 1994). In heterologous expression systems $\mathrm{I}_{\mathrm{Ks}}$ can be modulated through stimulation of both M1 and AT1 receptors. Acetylcholine and angiotensin II application results in a biphasic pattern of regulation with a transient increase followed by a marked and sustained inhibition. The activation phase may be regulated by PKC and the inhibitory phase is likely mediated through depletion of phosphatidylinositol-4,5-bisphosphate (Matavel and Lopes, 2009). In guinea pig myocytes an increase in nitric oxide acts to augment $\mathrm{I}_{\mathrm{Ks}}$ (Bai et al., 2005). It is thought this effect is mediated through S-nitrosylation of residue C445 in the C terminus of KCNQ1 (Asada et al., 2009). CamKII may activate the current though this has only been reported in sinoatrial nodal cells (Xie et al., 2015).

$I_{K r}$ : Currently there is no consensus regarding whether the activation of $\beta$-adrenoreceptors in cardiac myocytes regulates $\mathrm{I}_{\mathrm{Kr}}$ (for example see (Sanguinetti et al., 1991; Harmati et al., 2011). Interestingly, in heterologous expression systems the presence of different $\beta$ auxiliary subunits (either KCNE1 or KCNE2) in the channel complex can alter the responsiveness of the channel to $\beta$ adrenergic stimulation (Cui et al., 2000). It is therefore possible that the modulation of $\mathrm{I}_{\mathrm{Kr}}$ is species dependent and that the variable expression of auxiliary subunits could account for these differences. Increases in nitric oxide have been shown to modestly enhance $\mathrm{I}_{\mathrm{Kr}}$ current in guinea pig ventricular myocytes after overexpression of nitric oxide synthase 1 adaptor protein (Chang et al., 2008). $\mathrm{I}_{\mathrm{Kr}}$ density is also augmented by angiotensin II in guinea pig ventricular myocytes (Daleau and Turgeon, 1994).

$I_{K 1}$ : Isoproterenol and forskolin (a cAMP elevator) have been shown to inhibit $\mathrm{I}_{\mathrm{K} 1}$ density in human ventricular myocytes (Koumi et al., 1995). In contrast, in guinea pig ventricular myocytes 
isoproterenol moderately increased $I_{K 1}$ density (Banyasz et al., 2014). In canine left ventricular purkinje myocytes $\alpha$-adrenergic stimulation acts to decrease $I_{K 1}$ current and methoxamine (an $\alpha$ adrenergic receptor agonist) decreases the magnitude of $\mathrm{I}_{\mathrm{K} 1}$ in rabbit cardiomyocytes (Sosunov et al., 2004; Fedida et al., 1991). It is possible that angiotensin II may augment $\mathrm{I}_{\mathrm{K} 1}$ (Shimoni, 1999) and it has also been shown that nitric oxide augments $I_{K 1}$ density in human atrial cells. This is thought to be due to a direct effect of s-nitrosylation of the Kir2.1 residue C76 (Gomez et al., 2009). $I_{K A T P}$ : There are indications that $\mathrm{I}_{\mathrm{KATP}}$ can be activated by $\beta$-adrenergic stimulation and direct phosphorylation by PKA (Gonoi et al., 1999; Quinn et al., 2004). These effects have largely been studied in the equivalent of the pancreatic and vascular channels but it is clear that both the pore and sulphonylurea receptor contain potential phosphorylation sites. PKC and phosphatidylinositol-4,5bisphosphate depletion largely lead to inhibition though the effects can be complex and their physiological significance is unclear (Shyng and Nichols, 1998; Cole et al., 2000; Quinn et al., 2003). However the potential role of metabolic sensitivity of the channel is interesting. Mice with global genetic deletion of $\mathrm{K}_{\mathrm{ir}} 6.2$ have impaired exercise tolerance and a predisposition to arrhythmia (Zingman et al., 2002; Liu et al., 2004). Specifically they did not have appropriate action potential shortening on adrenergic challenge and developed afterdepolarisations (Liu et al., 2004). Thus $I_{\text {KATP }}$ together with $I_{\text {Ks }}$ may be involved in action potential shortening during exercise.

Other channels and transporters: There is some consensus that $\beta$-adrenergic stimulation and PKA activation increases the cardiac SCN5A sodium current (Matsuda et al., 1992). This probably occurs by direct channel phosphorylation and an increase in membrane channel activity. It may also promote the translocation of the sodium channel from perinuclear compartments to the plasma membrane (Murphy et al., 1996; Hallaq et al., 2006). Increases in intracellular calcium are probably inhibitory and this may be mediated by a direct pore blocking effect (Casini et al., 2009). The major connexion present in ventricular myocytes is $\mathrm{Cx} 43$. Regulatory pathways seem to influence the lifetime of the protein and cellular distribution being important in promotion of delivery to the intercalated disc and subsequent lateralisation to an inactive pool (Lambiase and Tinker, 2015). 
There are a number of serine phosphorylation sites in the C-terminus of the protein that can be engaged by PKC (Marquez-Rosado et al., 2012). As we have recently reviewed the exact details and the involvement of specific receptor pathways are complex (Lambiase and Tinker, 2015). There is however agreement that particularly in ischaemia $\mathrm{Cx} 43$ is dephosphorylated from its mature forms and this corresponds to lateralisation and impaired intermyocyte conduction (Peters et al., 1997; Beardslee et al., 2000). The sodium-calcium exchanger does not seem to be significantly modulated by phosphorylation (Bers, 2001).

Integrating the net effects of neuro-hormonal signalling on cellular electrophysiology: The unopposed activation of an inward current, such as the LTCC, would lead to action potential prolongation. The reverse would occur if outward potassium current increased without any other compensatory changes. In practice, the net effects of neuro-hormonal on the cardiac action potential are complex. Thus enhanced sympathetic drive increases both LTCC and $\mathrm{I}_{\mathrm{Ks}}$ but the APD shortens and together with greater recruitment at high rates is necessary for appropriate APD shortening. The parasympathetic system antagonises these effects. The importance of $\mathrm{I}_{\mathrm{Ks}}$ is illustrated in transgenic rabbits with transgenic suppression of the current when the action potential duration increases because of unopposed activation of LTCC (Liu et al., 2012).

Figure 1 summarises a potential consensus position on how cardiac ion channel currents might be potentially modulated by increased $\beta$-adrenergic drive.

\section{Regulation of ventricular excitability at the tissue level}

The tissue consequences of modulation of cellular electrophysiology are not always obvious and there remains a gap in understanding between cellular and basic electrophysiology and the clinical phenomena of cardiac arrhythmia (Pandit, 2010). A pertinent clinical question is why should an individual develop a specific arrhythmia at a particular time? In some cases a specific systemic upset can be pinpointed as being responsible for predilection to arrhythmia e.g. thyroid dysfunction, drug treatment or myocardial ischaemia. Yet, in many clinical arrhythmias, no specific 
major structural or functional change is ever identified coincident with the onset of arrhythmia. As we have detailed above cell signalling pathways and in particular the autonomic nervous system have a profound influence on cellular cardiac excitability. Detailing how it may modulate activation and repolarisation properties in tissue preparations and the whole heart, and thereby promote or supress clinical arrhythmia, is an important challenge. This is further accentuated when considering dynamic modulation, i.e. alterations in electrophysiology resulting from changes in coupling interval as well as variation stemming from autonomic stimuli. The very specific adaptation to heart rate by cardiac cells is termed "restitution" (Elzinga et al., 1981). The cardiac action potential tends to shorten in response to a decrease in coupling interval of successive beats. Specifically, APD restitution can be defined as a shortening of the APD in response to a decrease in the diastolic interval (DI) preceding that activation. A slower rate-dependence shortening, termed adaptation, may occur as a steady state cycle length is reduced (Taggart et al., 2003). Furthermore, slowing of conduction velocities occurs at very short diastolic intervals, observed in response to short coupling intervals.

The molecular basis of APD restitution and adaptation: Initially APD restitution was described in isolated cat papillary muscle and occurs in many other species including human cardiac tissue (Moore et al., 1965; Taggart et al., 2003). The ionic basis of cardiac restitution has been determined from experimental and computational studies. At long coupling intervals, the majority of repolarisation currents are through $\mathrm{I}_{\mathrm{Kr}}$. The importance of $\mathrm{I}_{\mathrm{Kr}}$ is exemplified by studies in rabbit models of LQT2 in which restitution slopes and the regional dispersion of those slopes are increased (Ziv et al., 2009).

$\mathrm{I}_{\mathrm{Ks}}$ appears to contribute very little to the repolarisation time course in the resting state at slow heart rates but its contribution increases at higher rates. Markov modelling has revealed how $\mathrm{I}_{\mathrm{Ks}}$ may contribute to cardiac restitution and adaptation (Silva and Rudy, 2005; Decker et al., 2009). The model consists of a group of 14 closed states corresponding to independent movement of the voltage sensors in each of the four subunits, a further closed state into which the channel complex 
transitions after all the voltage sensors have moved and two open states. The transition from deepinactive states to the inactive state is slow, whereas the time course of opening from an inactive state is rapid. Zones can be grouped into two inactive zones depending whether a voltage sensor exists in the deep-inactive state, as well as the channel open zone. In Zone 2, at least one channel subunit must transfer to the inactive state from the deep-inactive to allow channel opening to occur, whereas in Zone 1 all voltage sensors are in the inactive state. This provides an elegant model of how the contribution of $\mathrm{I}_{\mathrm{Ks}}$ to repolarisation can increase at short coupling intervals. During adaptation (i.e. at sustained short coupling intervals), there is accumulation of channels in Zone 1. As these are able to rapidly open, a "repolarisation reserve" of channels in state Zone 1 builds up, and the action potential shortens.

Action potential restitution can be seen as being due to a similar, albeit transient, increase in $\mathrm{I}_{\mathrm{Ks}}$ at short coupling intervals. At long coupling intervals, almost all $\mathrm{I}_{\mathrm{Ks}}$ channels exist in the deep inactive state at the start of the action potential. $\mathrm{I}_{\mathrm{Ks}}$ will transition to the inactive state with each action potential, but the long diastolic interval between activations allows the channels to fall back to the deep inactive state. A close-coupled $S_{2}$ beat will activate the cell prior to the full transition of $\mathrm{I}_{\mathrm{Ks}}$ to deep-inactive Zone 2 states, the proportion of channels in Zone 1 will still be elevated as a consequence of the previous activation. The more premature the $\mathrm{S}_{2}$, the greater the proportion of channels available in Zone 1 to rapidly open, and hence the greater the contribution to repolarisation from $\mathrm{I}_{\mathrm{Ks}}$. The net consequence is a greater repolarising current and a shorter action potential.

Accommodation may be seen as a separate but related phenomenon. It is observed that action potential duration does not reach a steady state following a change in constant pacing cycle length immediately, but requires several minutes before stabilisation. This phenomenon has not been fully explored at the molecular level, but changes in intracellular ionic concentrations, particularly of intracellular $\mathrm{Ca}^{2+}$ and $\mathrm{Na}^{+}$, may play a key role (Silva and Rudy, 2005).

The significance of restitution: Initially electrical restitution was described as being important in governing the contractile force generated following a premature beat (Kruta and Braveny, 1963). 
Interest in restitution properties grew as it became apparent that restitution could also be critical in explaining induction of heterogeneity in tissue that appeared homogenous during steady state activation. This is supported by the studies in the LQT2 rabbits mentioned above in which increased restitution slope and dispersion are associated with ventricular arrhythmia (Ziv et al., 2009). One manifestation of this is the conversion from stable to unstable APD alternans at short coupling intervals (Weiss et al., 2005). Indeed, half a century ago, Nolasco and Dahlen proposed a theoretical model predicting that APD restitution slopes of $>1$ would produce unstable responses to rapid cardiac stimuli, cumulating in APD alternans (Nolasco and Dahlen, 1968). This concept has been further refined via mathematical biodomain models, in one and two dimensions (Clayton and Taggart, 2005).

Regulation of restitution: It has been established in animal studies that adrenergic stimulation increases restitution slope and this is antagonised by vagal activation. Thus $\mathrm{Ng}$ and colleagues recorded monophasic action potentials in an isolated rabbit heart preparation that had intact autonomic innervation ( $\mathrm{Ng}$ et al., 2007). These studies revealed that sympathetic nerve stimulation results in increased restitution slope, decreased ERP and ventricular fibrillation threshold. Vagal nerve stimulation had the exact opposite effect and intriguingly later studies revealed that this was independent of ventricular muscarinic receptor activation and dependent on nitric oxide released from vagal nerve endings ( $\mathrm{Ng}$ et al., 2007; Brack et al., 2007; Brack et al., 2011). Our own recent studies showed that vagal innervation arising in the dorsal vagal motor nucleus in the brainstem resulted in a tonic protection against VT induction and was dependent on neuronal nitric oxide (Machhada et al., 2015). The adrenergic modulation of restitution also occurs in human hearts (Taggart et al., 2003). There may also be a kinetic mismatch between LTCC regulation and $\mathrm{I}_{\mathrm{Ks}}$ regulation by isoproterenol and this may lead to transient early afterdepolarisations (Xie et al., 2013).

Recently, we have described for the first time dynamic modulation of cardiac electrophysiology during experimentally induced mental stress (Finlay et al., 2015). Patients with 
structurally normal hearts attending for EP studies for ablation of supraventricular tachycardia underwent a psychometric relaxation protocol. During this, measurements of cardiac restitution were undertaken from the RV endocardium, LV endocardium and LV epicardium. The electrophysiological protocol was then repeated during coerced mental arithmetic and anger recall protocols. Marked changes in the dispersion of cardiac activation and repolarisation were observed during mental stress, particularly at short coupling intervals. One patient exhibited non-sustained polymorphic ventricular tachycardia under stress but not at rest. Interestingly, a particular feature of these studies was that as ERP reduced consequent to mental stress, the shortest coupling interval also reduced. However, at the shortest coupling intervals attained, the induced conduction delay (an inverse surrogate of conduction velocity) actually increased. Essentially, the cellular consequence of mental stress permitted "access" to shorter coupling intervals, at which cycle lengths the effect of induced conduction velocity slowing was magnified. So even a minor direct effect on conduction velocity may be bolstered by indirect effects, allowing extremely short coupling intervals to take place, the sequelae of which can be significant conduction velocity slowing. Figure 2 illustrates these phenomena.

Source-sink mismatch: Arrhythmia may be supressed electrotonically by surrounding tissue. Experimental and computational work indicates that this effect can be overcome by activation of $\beta$ adrenergic signalling which promotes $\mathrm{SR} \mathrm{Ca}^{2+}$ overload and promotion of tissue level excitation presenting as ventricular ectopics (Myles et al., 2012; Campos et al., 2015). However there has been little other work investigating the potential involvement of other signalling pathways.

Computational approaches: There is a long history of computational modelling in understanding cardiac biology (Noble, 1984; Noble, 2002; Mirams et al., 2012). Furthermore, there have been significant contributions in this area in an effort to understand the how cell signalling pathways regulate excitability. Specifically, models have shown that $\beta$-adrenergic mediated inotropy and lusitropy are heavily influenced by phospholamban regulation of SERCA2A activity and LTCC phosphorylation (Saucerman et al., 2003; Saucerman and McCulloch, 2004). At the cellular level 
investigators have recently focused on the adaptation of ventricular repolarisation during changes in heart rate (Pueyo et al., 2004; Pueyo et al., 2005; Pueyo et al., 2010) or with sympathetic drive or beat-to-beat variability occurring due to phasic oscillation in sympathetic tone and mechanical loading (Heijman et al., 2013). The accompanying modelling work reveals a complex interplay of various factors including $\mathrm{I}_{\mathrm{Ks}}$ and $\mathrm{I}_{\mathrm{Na}}$ regulation and sodium ion accumulation (Johnson et al., 2010; Pueyo et al., 2010; Pueyo et al., 2016).

Conduction velocity: Conduction velocity is often assumed to be a fixed value for a particular tissue, and little direct evidence exists other than the very steep electrical restitution observed just prior to ERP, termed conduction velocity restitution. This underlies the well-known "gap phenomenon", which describes the clinical observation of a very close coupled extrastimulus being conducted through the AV node whereas a slightly longer coupling interval resulted in conduction block. Our data imply a dynamism to conduction velocity previously underappreciated. Indeed, a feature of dynamic conduction velocity restitution is that it only takes place very close to the origin of the extra beat. Slowing of a wavefront of activation due to CV restitution protects downstream sites from further slowing (Finlay et al., 2014).

We can hypothesise several ionic and cellular mechanisms by which conduction velocity may be decreased at very short coupling intervals. As is seen in APD restitution, at short DIs, intracellular $\mathrm{Na}^{+}$increases as a result of inadequate extrusion via the $\mathrm{Na}^{+}-\mathrm{K}^{+}$exchanger and as a sequelae of intracellular $\mathrm{Ca}^{2+}$ increase. At very short coupling intervals, intracellular $\mathrm{Na}^{+}$could be high enough to reduce the velocity of the action potential upstroke by reducing the transmembrane $\mathrm{Na}^{+}$gradient and thereby slow conduction velocity. Sodium channels exists in several states, Markov models predict that at short coupling intervals fewer of them will have cycled through the conformational changes necessary to return them to a resting state. Thus at short DIs, membrane sodium channel availability will be reduced (O'Hara et al., 2011). Cycling of ion channels may also contribute to conduction slowing at short diastolic intervals. Though active at the cell membrane, the $\mathrm{Na}_{\mathrm{v}} 1.5$ protein and the connexin proteins exist in a state of equilibrium with subcellular 
apparatus (Hallaq et al., 2006; Lambiase and Tinker, 2015). It is possible, but as yet unproven, that altering the membrane locational equilibrium of either of these proteins will reduce cellular conductivity or excitability.

Dispersion of repolarisation: Another feature of the intact ventricle is that there is variation in action potential duration in different regions. The classical view is that there is a transmural difference in APD accounted for by differences in ion channel expression. The epicardial APD is shorter than the endocardial whilst M-cells resident in the mid-myocardium have the longest APD. Furthermore, epicardial and M cells have a prominent notch (spike and dome pattern) in the action potential accounted for by higher expression of $\mathrm{I}_{\mathrm{to}}$ (Litovsky and Antzelevitch, 1988; Antzelevitch, 1997; Wettwer et al., 1994). Furthermore, the $\mathrm{M}$ cell has lower expression levels of $\mathrm{I}_{\mathrm{Ks}}$ but not $\mathrm{I}_{\mathrm{Kr}}$ and $\mathrm{I}_{\mathrm{K} 1}$ (Liu et al., 1993; Liu and Antzelevitch, 1995). The existence of the M cell has been disputed however with the suggestion that in the intact heart apical-to-basal differences are more important (Janse et al., 2012). A recent mapping study in the human heart did not find a clear correlation with ion channel expression (Opthof et al., 2016). These cellular properties and whatever underlies them are thought to generate the characteristic properties of the T-wave on the ECG as reflected in Tpeak-Tend and QTc dispersion (Janse et al., 2012). It is clear spatial heterogeneity exists in the intact heart but its nature is more controversial than is generally accepted. Electrotonic and structural factors may be more important than is generally supposed.

Is this spatial dispersion of repolarisation under regulation by the autonomic nervous system? As we discuss below in a number of the channelopathy syndromes particular triggers, usually related to the adrenergic system, are often part of the disease history. Furthermore, it has been argued that the underlying genetic abnormalities accentuate spatial dispersion (Antzelevitch, 2007). There are data indicating that sympathetic drive in LQT1 may accentuate dispersion of repolarization (Tanabe et al., 2001). In more general terms there are animal data that showing that the dispersion of repolarisation is increased and the activation sequence may be changed from apex to base to base to apex with sympathetic activation (Yoshioka et al., 2000; Mantravadi et al., 2007). 
Interestingly this correlates with heterogeneous nervous innervation as much as differential ion channel expression. Finally, noradrenaline and sympathetic nerve stimulation are known to increase the restitution slope in spatially restricted fashion with greater shortening occurring at the base $(\mathrm{Ng}$ et al., 2009). This was sensitive to inhibition with $\mathrm{I}_{\mathrm{Ks}}$ blockers.

\section{Clinical Perspective}

Powerful direct and indirect evidence points to the role of modulation of autonomic tone in arrhythmogenesis. The reduction of cardiac arrhythmic death by $\beta$-blockade during myocardial infarction (MI) is the most widely known of these data and is supported by a substantial evidence base (Waagstein et al., 1993; Bristow et al., 1996; Hjalmarson et al., 2000; Poole-Wilson et al., 2003). $\beta$-blockers seem to have a significant effect on sudden cardiac death in this setting and lipophilic agents are especially valuable perhaps indicating some central effects or a unique protean signalling mechanism with carvedilol (Hjalmarson, 1999; Wisler et al., 2007).

The multi-tiered contribution of autonomic tone to cardiac arrhythmia onset is illustrated by numerous striking observations of increased arrhythmia frequency coincident with major psychological stress. These include earthquakes, missile (or threatened missile) attack and in the 911 World Trade Centre attacks (Leor et al., 1996; Niiyama et al., 2014; Meisel et al., 1991; Shedd et al., 2004; Steinberg et al., 2004). Eye-catching associations have also been made with the phenomenon of voodoo death and as an explanation for increased arrhythmic events during world cup football supporters (Lester, 2009; Wilbert-Lampen et al., 2008). More controlled data have shown ICD shocks to be associated with mental stress (Lampert et al., 2002; Lampert et al., 2005). Controlled laboratory experiments have solidified these associations. This work has been pioneered by Lampert and coworkers. In a series of elegant studies, mental stress was induced using a standardized series of psychometric tests, including mental arithmetic (reverse serial sevens with harsh encouragement) and anger recall (Lampert et al., 1994; Lampert et al., 2000; Stopper et al., 2007; Lampert, 2009; Abisse et al., 2011). These studies have examined the physiological effects 
on the 12-lead ECG and T-wave in particular of patients at risk of arrhythmia. Furthermore, they have documented increased frequencies of ICD discharges/therapies during periods of intense stress in ischaemic heart disease patients. Figure 3 shows an example of an ICD discharge in a patient with ischaemic heart disease watching a football match.

Previous works have also documented increased arrhythmogenicity in animal models during induced stress (Verrier and Lown, 1984) however less work has been done in man and in patients with cardiac disease. It has been hypothesized that mental stress can contribute to arrhythmia by increasing heterogeneities of repolarisation and activation (or conduction velocity) throughout the heart (Toivonen et al., 1997; Kop et al., 2004). These effects can thus amplify pre-existing heterogeneity, for example, due to ischemic heart disease or cardiomyopathy. These observations have been derived from the surface electrocardiogram, rather than cellular action potential or tissue electrogram measurements. Our recent work (see above) has begun to define the dynamic tissuelevel electrophysiology changes directly using invasive measurements performed in patients undergoing electrophysiological studies for benign arrhythmia investigations (Finlay et al., 2015). However, the emergence of new technologies, such as non-invasive electrical cardiac mapping (e.g. ECGi), has started to contribute to the understanding of the interplay between activation, repolarisation and their modulation with autonomic stimulation (Ghanem et al., 2005; Vijayakumar et al., 2014).

Mental stress induced arrhythmia is not a simple case of increased sympathetic drive. Rather, the sympathetic and parasympathetic axes appear to work in unison to optimise physiology to the perceived requirements of both bodily homeostasis and higher-level neuronal inputs. Several diseases have contributed disproportionally to our understanding of the interplay between autonomic and hormonal activation and the syndrome of cardiac arrhythmia, and Long QT syndrome type 1 (LQT1) and CPVT merit particular consideration.

Arrhythmic events in patients with LQT1 and CPVT are now well established to be dependent on high sympathetic tone with exercise being a particular trigger (Schwartz et al., 2001; 
Behere and Weindling, 2016). In LQT1, this dependence on exercise/increased adrenergic tone for arrhythmogenesis relates to the previously described dependence on $\mathrm{I}_{\mathrm{Ks}}$ augmentation for APD shortening at high heart rates. Clinically this mechanistic hypothesis is well corroborated because $\beta$ blocker therapy is extremely effective at preventing arrhythmic events in LQT1 patients (Vincent et al., 2009). A history of stressful life events and prolonged mental stress has also been associated with arrhythmia burden in Long-QT syndrome patients (Hintsa et al., 2010). Transgenic rabbit models of LQTS have provided a greater understanding of the triggers for arrhythmogenesis at the tissue and whole heart level and have confirmed the need for an additional specific stressor to induce arrhythmic events and sudden death in LQT1 but not LQT2 (Brunner et al., 2008; Lang et al., 2016). Additionally, transgenic LQT1 rabbit hearts, but not LQT2 rabbit hearts, display persistent early after depolarisations (EADs) at both the myocyte and whole heart level when perfused with isoprenaline (Liu et al., 2012). For CPVT, $\beta$-blocker therapy is less effective, compared to LQT1, and often these patients have an implantable cardioverter-defibrillator fitted. Unfortunately in these patients inappropriate shocks are relatively common and in some cases the stress associated with these events can feed back to promote further episodes of malignant arrhythmia (Miyake et al., 2013). Interestingly, swimming appears to be a particularly strong trigger for arrhythmia in patients with both LQT1 and CPVT. It has been postulated that this occurs because swimming activates both the sympathetic and parasympathetic autonomic systems, through the 'diving-reflex', and that the interplay between the two systems results in increased dispersion of refractoriness which can act as a substrate for arrhythmia development (Choi et al., 2004; Shattock and Tipton, 2012).

Diurnal variation in the timing of ventricular arrhythmia occurrence has been the subject of intense interest. In the Framingham study sudden cardiac death peaked between 7 and 9 am (Willich et al., 1987) and has been correlated to variations in ventricular refractoriness. The phenomenon of cyclical diurnal variation in incidence of arrhythmia is observed across subgroups in many diseases, for example ischaemic heart disease, Brugada syndrome (Matsuo et al., 1999), long QT syndromes 
or atrial fibrillation, though the "at risk" phase varies between conditions. The circadian clock is ultimately controlled by the suprachiasmatic nuclei of the anterior hypothalamus, which can be thought of as the "master clock", entraining circadian rhythms to the solar day (Reppert and Weaver, 2002). This overarching control entrains multiple circadian oscillators, existing across tissues and organs, including in brain tissue and peripheral organs. Such slave oscillators have even been demonstrated in immortalised cell lines in culture. In the heart, critical control of ion channel expression has been linked to such cellular clocks, under the control of krüppel-like factor 15 (Jeyaraj et al., 2012) and this has been shown to alter the expression of $\mathrm{I}_{\mathrm{to}}$ in a circadian manner, with overexpression promoting arrhythmia susceptibility in a mouse model. This cyclical temporal pattern of ion-channel expression can go some way towards explaining variations in the QT interval through the course of the day, with autonomic hormonal effects added on shorter time scales. Further, these intrinsic cellular changes in expression will interact functionally with the autonomic variation over the course of 24 hours, which may serve to further modulate cardiac electrophysiology and the propensity for arrhythmias.

Gender differences in cardiac electrophysiology have been recognised since the earliest days of study of the ECG (Bazett, 1920). The QT interval in females is longer than in males, and females with inherited LQT2 are at increased risk of arrhythmia and sudden cardiac death. There is strong element for a hormonal basis behind these differences, with no differences in QT interval between sexes prior to the onset of puberty. A role for testosterone is implied by the shortening of QTc in males at puberty, not seen in orchidectimised males. In females, a cyclical QT variation occurs with the menstrual cycle, and increases in arrhythmic risk in long-QT syndrome are observed in preganancy and post-partum (Rodriguez et al., 2001). The molecular mechanisms underlying such variations are complex and incompletely understood, and data exist pointing to both direct inhibition of currents (especiallyI $\mathrm{Kr}_{\mathrm{K}}$ ) by oestrogens (Kurokawa et al., 2008). Classical receptor mediated interactions have been shown to lead to changes in ion channel expression, the complexities of interactions with interspecies variation in experimental models can make dissection 
of pathways challenging (Odening and Koren, 2014; Odening, 2016). This modulation of electrophysiology by hormonal and circadian influences can have real clinical consequences, for example women are at much higher risk of drug-induced prolongation of the QT interval. Other hormonal modulators of cardiac electrophysiology are well known clinically. For example, thyroid function is tightly bound with arrhythmic risk, and thyroid dysfunction has been linked to both atrial and ventricular arrhythmic risk. Thyroid hormones have wide ranging modulation of gene expression, including regulation of the Na-K-ATPase, elements of calcium regulating system e.g. phospholamban, and also may have direct effects on ion channel function under specific conditions (Rajagopalan and Gerdes, 2015; Vargas-Uricoechea and Sierra-Torres, 2014). $\beta$-adrenoceptors are also under thyroid hormone control (Klein and Danzi, 2007). Hypopituitarism can also be associated with arrhythmia (KOSOWICZ and ROGUSKA, 1963). Given the exquisite regulation of the cardiac membrane potential, simultaneously on a beat-to-beat basis with daily or monthly hormonal changes, it is no surprise that complex interlocking and synergistic pathways may produce electrophysiological consequences.

In cardiac disease signalling pathways remodel but there is also evidence for changes in autonomic nervous innervation (Fukuda et al., 2015). Sympathetic nerve innervation is inhibited by sem3a derived from the endocardium during development. Overexpression or reduced expression of sem3a has consequences for ventricular excitability: specifically a mouse overexpressing the protein has readily inducible ventricular tachycardia (Ieda et al., 2007). In cardiac hypertrophy there is sympathetic hyperinnervation perhaps driven by nerve growth factor (Kimura et al., 2007). The situation in human heart failure is complex though with upregulation of sympathetic nerve activity but this is combined with reduced expression of tyrosine hydroxylase (Chidsey et al., 1962; Chidsey et al., 1963; Fukuda et al., 2015). Vagal nerve stimulation is being actively explored in heart failure. The CardioFit trial showed that the therapy was well tolerated in patients with heart failure (De Ferrari et al., 2011). However a randomised trial failed to demonstrate a change in the primary outcome namely left ventricular end-diastolic volume in the NECTER-HF trial but quality of life 
measures did show some improvement (Zannad et al., 2015). How vagal nerve stimulation might affect cardiac excitability and death from arrhythmia in heart failure remains to be tested. Finally, left cardiac sympathetic denervation has an established place in the management of LQTS and CPVT (Collura et al., 2009).

\section{Summary}

The hormonal regulation of ventricular excitability is important in arrhythmogenesis. The regulation by the autonomic nervous system of $\mathrm{I}_{\mathrm{Ks}}$, the LTCC and intracellular calcium handling in general are particularly important with an established and agreed evidence base. Traditionally, it has been asserted that noradrenaline and adrenaline acting on $\beta$-receptors and acetylcholine on muscarinic M2 receptors are key to changes in excitability by modulating the activity of PKA. Changes in PKA activity are important but it is also now clear that a number of other cellular pathways are operative particularly those involving CamKII and NO. Finally, there is a gap between our cellular understanding of ion channel regulation by the sympathetic and parasympathic nervous system and how this relates to tissue, organ and whole animal physiology and predisposition to arrhythmia. Spatial and rate dependent effects can be clearly influenced by autonomic signalling.

\section{Outlook}

A major challenge in this field is to be able to interpret, integrate and summate the effects of hormonal systems at the ionic, cellular and whole heart level. There is a wealth of experimental data analysing the effects of hormones on individual ionic currents and AP morphology but how this data translates from the cellular to whole heart level has not been extensively investigated. It is inherently difficult to interpret how changes in ionic current at the level of the myocyte will affect for example the complex mechanism of repolarisation. Intra-cardiac electrophysiological recordings and non-invasive mapping techniques such as non-invasive electrical cardiac mapping (e.g. ECGi) should provide insight and the use of computational modelling will help to integrate data from 
different sources and produce whole heart models (Rodriguez et al., 2015). Recently, an elegant paper by Sadrieh and colleagues reported the use of a multiscale and cutting edge computational approach to produce a whole heart model of why the T waves in LQT2 often have a notched or bifid appearance (Sadrieh et al., 2014). In the future, it may be possible to use similar computational approaches to integrate data from a wide variety of sources to produce models that can display and predict how particular hormonal systems control ventricular excitability. 


\section{Table Legend}

A Table summarising a potential consensus from the literature (see text for details and references) of the regulation of ion channels and the sodium-calcium exchanger by key signalling pathways related to autonomic modulation.

\section{Figure Legends}

Figure 1. Illustration of the effect of $\beta$-adrenergic receptor stimulation on the human ventricular action potential and the corresponding changes in the kinetics of the underlying currents. Upon sympathetic stimulation the action potential (AP) shortens (indicated by dashed red line). The increase in the $\mathrm{I}_{\mathrm{CaL}}$ current increases the height of the plateau phase and the increase in $\mathrm{I}_{\mathrm{Ks}}$ acts to shorten the time needed for phase 2 and 3 repolarisation to occur. The shortening of the AP allows for an increase in heart rate and reduces the effective refractory period. The references for the specific effects of $\beta$-AR signalling, and a detailed explanation, on the individual currents is provided in the main text. The current magnitudes represented in the lower panel are not to scale. $\checkmark$ : Strong experimentally confirmed effect; ?/ $\checkmark$ : Likely effect but no consensus; ?: No consensus.

\section{Figure 2. Progressive increase in dispersion of repolarisation with premature extrastimuli.} The panels demonstrate the dynamics of activation and repolarisation with prematurity of an ectopic or paced beat, from data derived from a mathematical model. Panel A shows that in general the measured times of activation increase more the further the measured site is from the pacing simulus (conduction delay of $0 \mathrm{~ms}$ ). Panel B demonstrates a model of restitution that can be applied to the repolarisation of cells. The repolarisation times at specific points (Panel C) are the sum of the conduction delay plus the restituting ARI. The cumulative effect of conduction delay principally occurs very close to the stimulus site, thus this is the area where most ARI restitution can occur. The combined effect is that repolarisation times near the stimulus site are reduced, whereas 
conduction delay protects distant sites from short diastolic intervals. The dispersion of repolarisation thus varies disproportionally more at sites close to the activation site following a premature extrastimuli (Panel D). Simulations using method described in (Finlay et al., 2013).

Figure 3. An implantable cardiovertor defibrillator recording of an episode of VT induced in a sports spectator. The patient, with an implantable cardioverter defibrillator and ischaemic heart disease, was watching a English premier league football match when he experienced palpitations and received a single therapy from his ICD. This occurred shortly after a series of missed opportunities by his team. Following this, he continued watching the rest of the game and attended the clinic later that day, where he underwent device interrogation. A single episode of VT follows a sinus tachycardia, and a "short-long-short" sequence of beats following a premature atrial complex (PAC) and ventricular ectopic (VE) trigger the onset of the ventricular tachycardia. The final score was a 2-1 loss. 


\section{Reference List}

Abbott,G.W., Sesti,F., Splawski,I., Buck,M.E., Lehmann,M.H., Timothy,K.W., Keating,M.T., and Goldstein,S.A. (1999). MiRP1 forms IKr potassium channels with HERG and is associated with cardiac arrhythmia. Cell 97, 175-187.

Abisse,S.S., Lampert,R., Burg,M., Soufer,R., and Shusterman,V. (2011). Cardiac repolarization instability during psychological stress in patients with ventricular arrhythmias. J. Electrocardiol. 44, 678-683.

Alloatti,G., Serazzi,L., and Levi,R.C. (1991). Prostaglandin I2 (PGI2) enhances calcium current in guinea-pig ventricular heart cells. J. Mol. Cell Cardiol. 23, 851-860.

An,W.F., Bowlby,M.R., Betty,M., Cao,J., Ling,H.P., Mendoza,G., Hinson,J.W., Mattsson,K.I., Strassle,B.W., Trimmer,J.S., and Rhodes,K.J. (2000). Modulation of A-type potassium channels by a family of calcium sensors. Nature 403, 553-556.

Anderson,M.E., Braun,A.P., Schulman,H., and Premack,B.A. (1994). Multifunctional $\mathrm{Ca} 2+/$ calmodulin-dependent protein kinase mediates $\mathrm{Ca}(2+)$-induced enhancement of the L-type $\mathrm{Ca} 2+$ current in rabbit ventricular myocytes. Circ. Res. 75, 854-861.

Antzelevitch,C. (1997). The M Cell. J. Cardiovasc. Pharmacol. Ther. 2, 73-76.

Antzelevitch,C. (2007). Role of spatial dispersion of repolarization in inherited and acquired sudden cardiac death syndromes. Am. J. Physiol Heart Circ. Physiol 293, H2024-H2038.

Apkon,M. and Nerbonne,J.M. (1988). Alpha 1-adrenergic agonists selectively suppress voltagedependent K+ current in rat ventricular myocytes. Proc. Natl. Acad. Sci. U. S. A 85, 8756-8760.

Armour,J.A. (2008). Potential clinical relevance of the 'little brain' on the mammalian heart. Exp. Physiol 93, 165-176.

Asada,K., Kurokawa,J., and Furukawa,T. (2009). Redox- and calmodulin-dependent S-nitrosylation of the KCNQ1 channel. J. Biol. Chem. 284, 6014-6020.

Bai,C.X., Kurokawa,J., Tamagawa,M., Nakaya,H., and Furukawa,T. (2005). Nontranscriptional regulation of cardiac repolarization currents by testosterone. Circulation 112, 1701-1710.

Banyasz,T., Jian,Z., Horvath,B., Khabbaz,S., Izu,L.T., and Chen-Izu,Y. (2014). Beta-adrenergic stimulation reverses the I Kr-I Ks dominant pattern during cardiac action potential. Pflugers Arch. 466, 2067-2076.

Barhanin,J., Lesage,F., Guillemare,E., Fink,M., Lazdunski,M., and Romey,G. (1996). K(V)LQT1 and lsK (minK) proteins associate to form the $\mathrm{I}(\mathrm{Ks})$ cardiac potassium current. Nature 384, 78-80.

Bazett,H.C. (1920). An analysis of the time-relations of electrocardiograms. Heart 7, 353-370.

Beardslee,M.A., Lerner,D.L., Tadros,P.N., Laing,J.G., Beyer,E.C., Yamada,K.A., Kleber,A.G., Schuessler,R.B., and Saffitz,J.E. (2000). Dephosphorylation and intracellular redistribution of ventricular connexin43 during electrical uncoupling induced by ischemia. Circ. Res. 87, 656-662. 
Behere,S.P. and Weindling,S.N. (2016). Catecholaminergic polymorphic ventricular tachycardia: An exciting new era. Ann. Pediatr. Cardiol. 9, 137-146.

Belardinelli,L. and Isenberg,G. (1983). Actions of adenosine and isoproterenol on isolated mammalian ventricular myocytes. Circ. Res. 53, 287-297.

Bell,D., Zhao,Y., McMaster,B., McHenry,E.M., Wang,X., Kelso,E.J., and McDermott,B.J. (2008). SRIF receptor subtype expression and involvement in positive and negative contractile effects of somatostatin-14 (SRIF-14) in ventricular cardiomyocytes. Cell Physiol Biochem. 22, 653-664.

Bennett,P.B. and Begenisich,T.B. (1987). Catecholamines modulate the delayed rectifying potassium current (IK) in guinea pig ventricular myocytes. Pflugers Arch. 410, 217-219.

Berridge,M.J. (2009). Inositol trisphosphate and calcium signalling mechanisms. Biochim. Biophys. Acta 1793, 933-940.

Bers,D.M. (2001). Na/Ca exchange and the Sarcolemmal Ca-pump. In Excitation-Contraction Coupling and Cardiac Contractile Force, Kluwer), pp. 133-160.

Bers,D.M. and Morotti,S. (2014). Ca(2+) current facilitation is CaMKII-dependent and has arrhythmogenic consequences. Front Pharmacol. 5, 144.

Blaich,A., Welling,A., Fischer,S., Wegener,J.W., Kostner,K., Hofmann,F., and Moosmang,S. (2010). Facilitation of murine cardiac L-type $\mathrm{Ca}(\mathrm{v}) 1.2$ channel is modulated by calmodulin kinase II-dependent phosphorylation of S1512 and S1570. Proc. Natl. Acad. Sci. U. S. A 107, 1028510289.

Boyett,M.R. and Fedida,D. (1988). The effect of heart rate on the membrane currents of isolated sheep Purkinje fibres. J. Physiol 399, 467-491.

Brack,K.E., Coote,J.H., and Ng,G.A. (2011). Vagus nerve stimulation protects against ventricular fibrillation independent of muscarinic receptor activation. Cardiovasc. Res. 91, 437-446.

Brack,K.E., Patel,V.H., Coote,J.H., and Ng,G.A. (2007). Nitric oxide mediates the vagal protective effect on ventricular fibrillation via effects on action potential duration restitution in the rabbit heart. J. Physiol 583, 695-704.

Bristow,M.R., Gilbert,E.M., Abraham,W.T., Adams,K.F., Fowler,M.B., Hershberger,R.E., Kubo,S.H., Narahara,K.A., Ingersoll,H., Krueger,S., Young,S., and Shusterman,N. (1996). Carvedilol produces dose-related improvements in left ventricular function and survival in subjects with chronic heart failure. MOCHA Investigators. Circulation 94, 2807-2816.

Brodde,O.E. (1991). Beta 1- and beta 2-adrenoceptors in the human heart: properties, function, and alterations in chronic heart failure. Pharmacol. Rev. 43, 203-242.

Brunner,M., Peng,X., Liu,G.X., Ren,X.Q., Ziv,O., Choi,B.R., Mathur,R., Hajjiri,M., Odening,K.E., Steinberg,E., Folco,E.J., Pringa,E., Centracchio,J., Macharzina,R.R., Donahay,T., Schofield,L., Rana,N., Kirk,M., Mitchell,G.F., Poppas,A., Zehender,M., and Koren,G. (2008). Mechanisms of cardiac arrhythmias and sudden death in transgenic rabbits with long QT syndrome. J. Clin. Invest $118,2246-2259$.

Caballero,R., Gomez,R., Moreno,I., Nunez,L., Gonzalez,T., Arias,C., Guizy,M., Valenzuela,C., Tamargo,J., and Delpon,E. (2004). Interaction of angiotensin II with the angiotensin type 2 receptor inhibits the cardiac transient outward potassium current. Cardiovasc. Res. 62, 86-95. 
Camors,E. and Valdivia,H.H. (2014). CaMKII regulation of cardiac ryanodine receptors and inositol triphosphate receptors. Front Pharmacol. 5, 101.

Campos,F.O., Shiferaw,Y., Prassl,A.J., Boyle,P.M., Vigmond,E.J., and Plank,G. (2015). Stochastic spontaneous calcium release events trigger premature ventricular complexes by overcoming electrotonic load. Cardiovasc. Res. 107, 175-183.

Casini,S., Verkerk,A.O., van Borren,M.M., van Ginneken,A.C., Veldkamp,M.W., de Bakker,J.M., and Tan,H.L. (2009). Intracellular calcium modulation of voltage-gated sodium channels in ventricular myocytes. Cardiovasc. Res. 81, 72-81.

Catterall,W.A. (2012). Voltage-gated sodium channels at 60: structure, function and pathophysiology. J. Physiol 590, 2577-2589.

Caulfield,M.P. and Birdsall,N.J. (1998). International Union of Pharmacology. XVII. Classification of muscarinic acetylcholine receptors. Pharmacol. Rev. 50, 279-290.

Chang,K.C., Barth,A.S., Sasano,T., Kizana,E., Kashiwakura,Y., Zhang,Y., Foster,D.B., and Marban,E. (2008). CAPON modulates cardiac repolarization via neuronal nitric oxide synthase signaling in the heart. Proc. Natl. Acad. Sci. U. S. A 105, 4477-4482.

Chen,F., Spicher,K., Jiang,M., Birnbaumer,L., and Wetzel,G.T. (2001). Lack of muscarinic regulation of $\mathrm{Ca}(2+)$ channels in $\mathrm{G}(\mathrm{i} 2)$ alpha gene knockout mouse hearts. Am. J. Physiol Heart Circ. Physiol 280, H1989-H1995.

Chen,L., Kurokawa,J., and Kass,R.S. (2005). Phosphorylation of the A-kinase-anchoring protein Yotiao contributes to protein kinase A regulation of a heart potassium channel. J. Biol. Chem. 280, 31347-31352.

Chesley,A., Lundberg,M.S., Asai,T., Xiao,R.P., Ohtani,S., Lakatta,E.G., and Crow,M.T. (2000). The beta(2)-adrenergic receptor delivers an antiapoptotic signal to cardiac myocytes through G(i)dependent coupling to phosphatidylinositol 3'-kinase. Circ. Res. 87, 1172-1179.

Chidsey,C.A., Braunwald,E., Morrow,A.G., and Mason,D.T. (1963). MYOCARDIAL NOREPINEPHRINE CONCENTRATION IN MAN. EFFECTS OF RESERPINE AND OF CONGESTIVE HEART FAILURE. N. Engl. J. Med. 269, 653-658.

Chidsey,C.A., Harrison,D.C., and Braunwald,E. (1962). Augmentation of the plasma norepinephrine response to exercise in patients with congestive heart failure. N. Engl. J. Med. 267, 650-654.

Choi,G., Kopplin,L.J., Tester,D.J., Will,M.L., Haglund,C.M., and Ackerman,M.J. (2004). Spectrum and frequency of cardiac channel defects in swimming-triggered arrhythmia syndromes. Circulation $110,2119-2124$.

Christophe,J., Waelbroeck,M., Chatelain,P., and Robberecht,P. (1984). Heart receptors for VIP, $\mathrm{PHI}$ and secretin are able to activate adenylate cyclase and to mediate inotropic and chronotropic effects. Species variations and physiopathology. Peptides 5, 341-353.

Clayton,R.H. and Taggart,P. (2005). Regional differences in APD restitution can initiate wavebreak and re-entry in cardiac tissue: a computational study. Biomed. Eng Online. 4, 54.

Cole,W.C., Malcolm,T., Walsh,M.P., and Light,P.E. (2000). Inhibition by protein kinase C of the K(NDP) subtype of vascular smooth muscle ATP-sensitive potassium channel. Circ. Res. 87, 112- 
117.

Collura,C.A., Johnson,J.N., Moir,C., and Ackerman,M.J. (2009). Left cardiac sympathetic denervation for the treatment of long QT syndrome and catecholaminergic polymorphic ventricular tachycardia using video-assisted thoracic surgery. Heart Rhythm. 6, 752-759.

Coote,J.H. (2013). Myths and Realities of the Cardiac Vagus. J. Physiol.

Cui,J., Melman,Y., Palma,E., Fishman,G.I., and McDonald,T.V. (2000). Cyclic AMP regulates the HERG K(+) channel by dual pathways. Curr. Biol. 10, 671-674.

Daleau,P. and Turgeon,J. (1994). Angiotensin II modulates the delayed rectifier potassium current of guinea pig ventricular myocytes. Pflugers Arch. 427, 553-555.

Davis,R.P., van den Berg,C.W., Casini,S., Braam,S.R., and Mummery,C.L. (2011). Pluripotent stem cell models of cardiac disease and their implication for drug discovery and development. Trends Mol. Med. 17, 475-484.

De Ferrari,G.M., Crijns,H.J., Borggrefe,M., Milasinovic,G., Smid,J., Zabel,M., Gavazzi,A., Sanzo,A., Dennert,R., Kuschyk,J., Raspopovic,S., Klein,H., Swedberg,K., and Schwartz,P.J. (2011). Chronic vagus nerve stimulation: a new and promising therapeutic approach for chronic heart failure. Eur. Heart J. 32, 847-855.

De,K.P. and Schulman,H. (1998). Sensitivity of CaM kinase II to the frequency of Ca2+ oscillations. Science 279, 227-230.

Decker,K.F., Heijman,J., Silva,J.R., Hund,T.J., and Rudy,Y. (2009). Properties and ionic mechanisms of action potential adaptation, restitution, and accommodation in canine epicardium. Am. J. Physiol Heart Circ. Physiol 296, H1017-H1026.

Diviani,D., Reggi,E., Arambasic,M., Caso,S., and Maric,D. (2015). Emerging roles of A-kinase anchoring proteins in cardiovascular pathophysiology. Biochim. Biophys. Acta.

Dixon,J.E., Shi,W., Wang,H.S., McDonald,C., Yu,H., Wymore,R.S., Cohen,I.S., and McKinnon,D. (1996). Role of the Kv4.3 K+ channel in ventricular muscle. A molecular correlate for the transient outward current. Circ. Res. 79, 659-668.

Elzinga,G., Lab,M.J., Noble,M.I., Papadoyannis,D.E., Pidgeon,J., Seed,A., and Wohlfart,B. (1981). The action-potential duration and contractile response of the intact heart related to the preceding interval and the preceding beat in the dog and cat. J. Physiol 314, 481-500.

Endoh,M. (1996). Cardiac alpha(1)-adrenoceptors that regulate contractile function: subtypes and subcellular signal transduction mechanisms. Neurochem. Res. 21, 217-229.

Endoh,M., Otomo,J., Norota,I., and Takanashi,M. (1993). Selective inhibition by phorbol 12,13dibutyrate of the alpha 1-receptor-mediated positive inotropic effect. Int. J. Cardiol. 40, 191-201.

Erickson,J.R. (2014). Mechanisms of CaMKII Activation in the Heart. Front Pharmacol. 5, 59.

Fabiato,A. (1985). Time and calcium dependence of activation and inactivation of calcium-induced release of calcium from the sarcoplasmic reticulum of a skinned canine cardiac Purkinje cell. J. Gen. Physiol 85, 247-289.

Fedida,D., Braun,A.P., and Giles,W.R. (1991). Alpha 1-adrenoceptors reduce background K+ 
current in rabbit ventricular myocytes. J. Physiol 441, 673-684.

Feron,O., Belhassen,L., Kobzik,L., Smith,T.W., Kelly,R.A., and Michel,T. (1996). Endothelial nitric oxide synthase targeting to caveolae. Specific interactions with caveolin isoforms in cardiac myocytes and endothelial cells. J. Biol. Chem. 271, 22810-22814.

Finlay,M.C., Ahmed,A.K., Sugrue,A., Bhar-Amato,J., Quarta,G., Pantazis,A., Ciaccio,E.J., Syrris,P., Sen-Chowdhry,S., Ben-Simon,R., Chow,A.W., Lowe,M.D., Segal,O.R., McKenna,W.J., and Lambiase,P.D. (2014). Dynamic conduction and repolarisation changes in early arrhythmogenic right ventricular cardiomyopathy versus benign outflow tract ectopy demonstrated by high density mapping \& paced surface ECG analysis. PLoS. One. 9, e99125.

Finlay,M.C., Lambiase,P.D., Ben-Simon,R., and Taggart,P. (2015). Effect of mental stress on dynamic electrophysiological properties of the endocardium and epicardium in humans. Heart Rhythm.

Finlay,M.C., Xu,L., Taggart,P., Hanson,B., and Lambiase,P.D. (2013). Bridging the gap between computation and clinical biology: validation of cable theory in humans. Front Physiol 4, 213.

Follmann,M., Griebenow,N., Hahn,M.G., Hartung,I., Mais,F.J., Mittendorf,J., Schafer,M., Schirok,H., Stasch,J.P., Stoll,F., and Straub,A. (2013). The chemistry and biology of soluble guanylate cyclase stimulators and activators. Angew. Chem. Int. Ed Engl. 52, 9442-9462.

Foster,M.W., Hess,D.T., and Stamler,J.S. (2009). Protein S-nitrosylation in health and disease: a current perspective. Trends Mol. Med. 15, 391-404.

Fraser,I.D., Tavalin,S.J., Lester,L.B., Langeberg,L.K., Westphal,A.M., Dean,R.A., Marrion,N.V., and Scott,J.D. (1998). A novel lipid-anchored A-kinase Anchoring Protein facilitates cAMPresponsive membrane events. EMBO J. 17, 2261-2272.

Fujii,J., Zarain-Herzberg,A., Willard,H.F., Tada,M., and MacLennan,D.H. (1991). Structure of the rabbit phospholamban gene, cloning of the human cDNA, and assignment of the gene to human chromosome 6. J. Biol. Chem. 266, 11669-11675.

Fukuda,K., Kanazawa,H., Aizawa,Y., Ardell,J.L., and Shivkumar,K. (2015). Cardiac innervation and sudden cardiac death. Circ. Res. 116, 2005-2019.

Gallo,M.P., Ghigo,D., Bosia,A., Alloatti,G., Costamagna,C., Penna,C., and Levi,R.C. (1998). Modulation of guinea-pig cardiac L-type calcium current by nitric oxide synthase inhibitors. J. Physiol 506 ( Pt 3), 639-651.

Gallo,M.P., Malan,D., Bedendi,I., Biasin,C., Alloatti,G., and Levi,R.C. (2001). Regulation of cardiac calcium current by NO and cGMP-modulating agents. Pflugers Arch. 441, 621-628.

Ghanem,R.N., Jia,P., Ramanathan,C., Ryu,K., Markowitz,A., and Rudy,Y. (2005). Noninvasive electrocardiographic imaging (ECGI): comparison to intraoperative mapping in patients. Heart Rhythm. 2, 339-354.

Gomez,R., Caballero,R., Barana,A., Amoros,I., Calvo,E., Lopez,J.A., Klein,H., Vaquero,M., Osuna,L., Atienza,F., Almendral,J., Pinto,A., Tamargo,J., and Delpon,E. (2009). Nitric oxide increases cardiac IK1 by nitrosylation of cysteine 76 of Kir2.1 channels. Circ. Res. 105, 383-392.

Gomez,R., Nunez,L., Vaquero,M., Amoros,I., Barana,A., de,P.T., Macaya,C., Maroto,L., Rodriguez,E., Caballero,R., Lopez-Farre,A., Tamargo,J., and Delpon,E. (2008). Nitric oxide 
inhibits Kv4.3 and human cardiac transient outward potassium current (Ito1). Cardiovasc. Res. 80, 375-384.

Gonoi,T., Nagashima,K., Nishimura,M., and Seino,S. (1999). PKA-mediated phosphorylation of the human $\mathrm{K}_{\mathrm{ATP}}$ channel: separate roles of Kir6.2 and SUR1 subunit phosphorylation. EMBO J. 18, $4722-4732$.

Grueter,C.E., Abiria,S.A., Dzhura,I., Wu,Y., Ham,A.J., Mohler,P.J., Anderson,M.E., and Colbran,R.J. (2006). L-type Ca2+ channel facilitation mediated by phosphorylation of the beta subunit by CaMKII. Mol. Cell 23, 641-650.

Hallaq,H., Yang,Z., Viswanathan,P.C., Fukuda,K., Shen,W., Wang,D.W., Wells,K.S., Zhou,J., Yi,J., and Murray,K.T. (2006). Quantitation of protein kinase A-mediated trafficking of cardiac sodium channels in living cells. Cardiovasc. Res. 72, 250-261.

Harmati,G., Banyasz,T., Barandi,L., Szentandrassy,N., Horvath,B., Szabo,G., Szentmiklosi,J.A., Szenasi,G., Nanasi,P.P., and Magyar,J. (2011). Effects of beta-adrenoceptor stimulation on delayed rectifier $\mathrm{K}(+)$ currents in canine ventricular cardiomyocytes. Br. J. Pharmacol. 162, 890-896.

Heijman,J., Zaza,A., Johnson,D.M., Rudy,Y., Peeters,R.L., Volders,P.G., and Westra,R.L. (2013). Determinants of beat-to-beat variability of repolarization duration in the canine ventricular myocyte: a computational analysis. PLoS. Comput. Biol. 9, e1003202.

Hintsa,T., Puttonen,S., Toivonen,L., Kontula,K., Swan,H., and Keltikangas-Jarvinen,L. (2010). A history of stressful life events, prolonged mental stress and arrhythmic events in inherited long QT syndrome. Heart 96, 1281-1286.

Hjalmarson,A. (1999). Prevention of sudden cardiac death with beta blockers. Clin. Cardiol. 22 Suppl 5, V11-V15.

Hjalmarson,A., Goldstein,S., Fagerberg,B., Wedel,H., Waagstein,F., Kjekshus,J., Wikstrand,J., El,A.D., Vitovec,J., Aldershvile,J., Halinen,M., Dietz,R., Neuhaus,K.L., Janosi,A., Thorgeirsson,G., Dunselman,P.H., Gullestad,L., Kuch,J., Herlitz,J., Rickenbacher,P., Ball,S., Gottlieb,S., and Deedwania,P. (2000). Effects of controlled-release metoprolol on total mortality, hospitalizations, and well-being in patients with heart failure: the Metoprolol CR/XL Randomized Intervention Trial in congestive heart failure (MERIT-HF). MERIT-HF Study Group. JAMA 283, 1295-1302.

Hryshko,L.V. and Bers,D.M. (1990). Ca current facilitation during postrest recovery depends on Ca entry. Am. J. Physiol 259, H951-H961.

Hu,H., Chiamvimonvat,N., Yamagishi,T., and Marban,E. (1997). Direct inhibition of expressed cardiac L-type Ca2+ channels by S-nitrosothiol nitric oxide donors. Circ. Res. 81, 742-752.

Hudmon,A., Schulman,H., Kim,J., Maltez,J.M., Tsien,R.W., and Pitt,G.S. (2005). CaMKII tethers to L-type $\mathrm{Ca} 2+$ channels, establishing a local and dedicated integrator of $\mathrm{Ca} 2+$ signals for facilitation. J. Cell Biol. 171, 537-547.

Hulme,J.T., Westenbroek,R.E., Scheuer,T., and Catterall,W.A. (2006). Phosphorylation of serine 1928 in the distal C-terminal domain of cardiac CaV1.2 channels during beta1-adrenergic regulation. Proc. Natl. Acad. Sci. U. S. A 103, 16574-16579.

Ieda,M., Kanazawa,H., Kimura,K., Hattori,F., Ieda,Y., Taniguchi,M., Lee,J.K., Matsumura,K., Tomita,Y., Miyoshi,S., Shimoda,K., Makino,S., Sano,M., Kodama,I., Ogawa,S., and Fukuda,K. 
(2007). Sema3a maintains normal heart rhythm through sympathetic innervation patterning. Nat. Med. 13, 604-612.

Irie,T., Sips,P.Y., Kai,S., Kida,K., Ikeda,K., Hirai,S., Moazzami,K., Jiramongkolchai,P., Bloch,D.B., Doulias,P.T., Armoundas,A.A., Kaneki,M., Ischiropoulos,H., Kranias,E., Bloch,K.D., Stamler,J.S., and Ichinose,F. (2015). S-Nitrosylation of Calcium-Handling Proteins in Cardiac Adrenergic Signaling and Hypertrophy. Circ. Res. 117, 793-803.

Janse,M.J., Coronel,R., Opthof,T., Sosunov,E.A., Anyukhovsky,E.P., and Rosen,M.R. (2012). Repolarization gradients in the intact heart: transmural or apico-basal? Prog. Biophys. Mol. Biol. 109, 6-15.

Jeyaraj,D., Haldar,S.M., Wan,X., McCauley,M.D., Ripperger,J.A., Hu,K., Lu,Y., Eapen,B.L., Sharma,N., Ficker,E., Cutler,M.J., Gulick,J., Sanbe,A., Robbins,J., Demolombe,S., Kondratov,R.V., Shea,S.A., Albrecht,U., Wehrens,X.H., Rosenbaum,D.S., and Jain,M.K. (2012). Circadian rhythms govern cardiac repolarization and arrhythmogenesis. Nature 483, 96-99.

Johnson,D.M., Heijman,J., Pollard,C.E., Valentin,J.P., Crijns,H.J., Abi-Gerges,N., and Volders,P.G. (2010). I(Ks) restricts excessive beat-to-beat variability of repolarization during beta-adrenergic receptor stimulation. J. Mol. Cell Cardiol. 48, 122-130.

Kahsai,A.W., Xiao,K., Rajagopal,S., Ahn,S., Shukla,A.K., Sun,J., Oas,T.G., and Lefkowitz,R.J. (2011). Multiple ligand-specific conformations of the beta2-adrenergic receptor. Nat. Chem. Biol. 7, 692-700.

Kamp,T.J. and Hell,J.W. (2000). Regulation of cardiac L-type calcium channels by protein kinase A and protein kinase C. Circ. Res. 87, 1095-1102.

Kass,R.S. and Sanguinetti,M.C. (1984). Inactivation of calcium channel current in the calf cardiac Purkinje fiber. Evidence for voltage- and calcium-mediated mechanisms. J. Gen. Physiol 84, 705726.

Kimura,K., Ieda,M., Kanazawa,H., Yagi,T., Tsunoda,M., Ninomiya,S., Kurosawa,H., Yoshimi,K., Mochizuki,H., Yamazaki,K., Ogawa,S., and Fukuda,K. (2007). Cardiac sympathetic rejuvenation: a link between nerve function and cardiac hypertrophy. Circ. Res. 100, 1755-1764.

Klein,I. and Danzi,S. (2007). Thyroid disease and the heart. Circulation 116, 1725-1735.

Kop,W.J., Krantz,D.S., Nearing,B.D., Gottdiener,J.S., Quigley,J.F., O'Callahan,M., DelNegro,A.A., Friehling,T.D., Karasik,P., Suchday,S., Levine,J., and Verrier,R.L. (2004). Effects of acute mental stress and exercise on T-wave alternans in patients with implantable cardioverter defibrillators and controls. Circulation 109, 1864-1869.

KOSOWICZ,J. and ROGUSKA,J. (1963). Electrocardiogram in hypopituitarism. Reversibility of changes during treatment. Am. Heart J. 65, 17-23.

Koumi,S., Wasserstrom,J.A., and Ten Eick,R.E. (1995). Beta-adrenergic and cholinergic modulation of inward rectifier $\mathrm{K}+$ channel function and phosphorylation in guinea-pig ventricle. $\mathrm{J}$. Physiol 486 ( Pt 3), 661-678.

Kranias,E.G. and Solaro,R.J. (1982). Phosphorylation of troponin I and phospholamban during catecholamine stimulation of rabbit heart. Nature 298, 182-184.

Kruta,V. and Braveny,P. (1963). Rate of restitution and self-regulation of contractility in 
mammalian heart muscle. Nature 197, 905-906.

Kurokawa,J., Chen,L., and Kass,R.S. (2003). Requirement of subunit expression for cAMPmediated regulation of a heart potassium channel. Proc. Natl. Acad. Sci. U. S. A 100, 2122-2127.

Kurokawa,J., Tamagawa,M., Harada,N., Honda,S., Bai,C.X., Nakaya,H., and Furukawa,T. (2008). Acute effects of oestrogen on the guinea pig and human IKr channels and drug-induced prolongation of cardiac repolarization. J. Physiol 586, 2961-2973.

Lambiase,P.D. and Tinker,A. (2015). Connexins in the heart. Cell Tissue Res. 360, 675-684.

Lampert,R. (2009). Emotion and sudden cardiac death. Expert. Rev. Cardiovasc. Ther. 7, 723-725.

Lampert,R., Jain,D., Burg,M.M., Batsford,W.P., and McPherson,C.A. (2000). Destabilizing effects of mental stress on ventricular arrhythmias in patients with implantable cardioverter-defibrillators. Circulation 101, 158-164.

Lampert,R., Joska,T., Burg,M.M., Batsford,W.P., McPherson,C.A., and Jain,D. (2002). Emotional and physical precipitants of ventricular arrhythmia. Circulation 106, 1800-1805.

Lampert,R., Rosenfeld,L., Batsford,W., Lee,F., and McPherson,C. (1994). Circadian variation of sustained ventricular tachycardia in patients with coronary artery disease and implantable cardioverter-defibrillators. Circulation 90, 241-247.

Lampert,R., Shusterman,V., Burg,M.M., Lee,F.A., Earley,C., Goldberg,A., McPherson,C.A., Batsford,W.P., and Soufer,R. (2005). Effects of psychologic stress on repolarization and relationship to autonomic and hemodynamic factors. J. Cardiovasc. Electrophysiol. 16, 372-377.

Lang,C.N., Koren,G., and Odening,K.E. (2016). Transgenic rabbit models to investigate the cardiac ion channel disease long QT syndrome. Prog. Biophys. Mol. Biol.

Lee,T.S., Karl,R., Moosmang,S., Lenhardt,P., Klugbauer,N., Hofmann,F., Kleppisch,T., and Welling,A. (2006). Calmodulin kinase II is involved in voltage-dependent facilitation of the L-type Cav1.2 calcium channel: Identification of the phosphorylation sites. J. Biol. Chem. 281, 2556025567.

Lefkowitz,R.J. and Shenoy,S.K. (2005). Transduction of receptor signals by beta-arrestins. Science 308, 512-517.

Leor,J., Poole,W.K., and Kloner,R.A. (1996). Sudden cardiac death triggered by an earthquake. N. Engl. J. Med. 334, 413-419.

Lesage,F. and Lazdunski,M. (2000). Molecular and functional properties of two-pore-domain potassium channels. Am. J. Physiol Renal Physiol 279, F793-F801.

Lester,D. (2009). Voodoo death. Omega. (Westport. ) 59, 1-18.

Levi,R., Capurro,N., and Lee,C.H. (1975). Pharmacological characterization of cardiac histamine receptors: sensitivity to H1-and H2-receptor agonists and antagonists. Eur. J. Pharmacol. 30, 328335.

Lewis,M.E., Al-Khalidi,A.H., Bonser,R.S., Clutton-Brock,T., Morton,D., Paterson,D., Townend,J.N., and Coote,J.H. (2001). Vagus nerve stimulation decreases left ventricular contractility in vivo in the human and pig heart. J. Physiol 534, 547-552. 
Lezoualc'h,F., Fazal,L., Laudette,M., and Conte,C. (2016). Cyclic AMP Sensor EPAC Proteins and Their Role in Cardiovascular Function and Disease. Circ. Res. 118, 881-897.

Li,L., DeSantiago,J., Chu,G., Kranias,E.G., and Bers,D.M. (2000). Phosphorylation of phospholamban and troponin I in beta-adrenergic-induced acceleration of cardiac relaxation. Am. J. Physiol Heart Circ. Physiol 278, H769-H779.

Litovsky,S.H. and Antzelevitch,C. (1988). Transient outward current prominent in canine ventricular epicardium but not endocardium. Circ. Res. 62, 116-126.

Liu,D.W. and Antzelevitch,C. (1995). Characteristics of the delayed rectifier current (IKr and IKs) in canine ventricular epicardial, midmyocardial, and endocardial myocytes. A weaker IKs contributes to the longer action potential of the M cell. Circ. Res. 76, 351-365.

Liu,D.W., Gintant,G.A., and Antzelevitch,C. (1993). Ionic bases for electrophysiological distinctions among epicardial, midmyocardial, and endocardial myocytes from the free wall of the canine left ventricle. Circ. Res. 72, 671-687.

Liu,G.X., Choi,B.R., Ziv,O., Li,W., de,L.E., Qu,Z., and Koren,G. (2012). Differential conditions for early after-depolarizations and triggered activity in cardiomyocytes derived from transgenic LQT1 and LQT2 rabbits. J. Physiol 590, 1171-1180.

Liu,G.X., Derst,C., Schlichthorl,G., Heinen,S., Seebohm,G., Bruggemann,A., Kummer,W., Veh,R.W., Daut,J., and Preisig-Muller,R. (2001). Comparison of cloned Kir2 channels with native inward rectifier K+ channels from guinea-pig cardiomyocytes. J. Physiol 532, 115-126.

Liu,X.K., Yamada,S., Kane,G.C., Alekseev,A.E., Hodgson,D.M., O'Cochlain,F., Jahangir,A., Miki,T., Seino,S., and Terzic,A. (2004). Genetic disruption of Kir6.2, the pore-forming subunit of ATP-sensitive $\mathrm{K}+$ channel, predisposes to catecholamine-induced ventricular dysrhythmia. Diabetes 53 Suppl 3, S165-S168.

London,B., Wang,D.W., Hill,J.A., and Bennett,P.B. (1998). The transient outward current in mice lacking the potassium channel gene Kv1.4. J. Physiol 509 ( Pt 1), 171-182.

Machhada,A., Ang,R., Ackland,G.L., Ninkina,N., Buchman,V.L., Lythgoe,M.F., Trapp,S., Tinker,A., Marina,N., and Gourine,A.V. (2015). Control of ventricular excitability by neurons of the dorsal motor nucleus of the vagus nerve. Heart Rhythm. 12, 2285-2293.

Mantravadi,R., Gabris,B., Liu,T., Choi,B.R., de Groat,W.C., Ng,G.A., and Salama,G. (2007). Autonomic nerve stimulation reverses ventricular repolarization sequence in rabbit hearts. Circ. Res. 100, e72-e80.

Marquez-Rosado,L., Solan,J.L., Dunn,C.A., Norris,R.P., and Lampe,P.D. (2012). Connexin43 phosphorylation in brain, cardiac, endothelial and epithelial tissues. Biochim. Biophys. Acta 1818, 1985-1992.

Marx,S.O., Kurokawa,J., Reiken,S., Motoike,H., D'Armiento,J., Marks,A.R., and Kass,R.S. (2002). Requirement of a macromolecular signaling complex for beta adrenergic receptor modulation of the KCNQ1-KCNE1 potassium channel. Science 295, 496-499.

Matavel,A. and Lopes,C.M. (2009). PKC activation and PIP(2) depletion underlie biphasic regulation of IKs by Gq-coupled receptors. J. Mol. Cell Cardiol. 46, 704-712.

Matsuda,J.J., Lee,H., and Shibata,E.F. (1992). Enhancement of rabbit cardiac sodium channels by 
beta-adrenergic stimulation. Circ. Res. 70, 199-207.

Matsuo,K., Kurita,T., Inagaki,M., Kakishita,M., Aihara,N., Shimizu,W., Taguchi,A., Suyama,K., Kamakura,S., and Shimomura,K. (1999). The circadian pattern of the development of ventricular fibrillation in patients with Brugada syndrome. Eur. Heart J. 20, 465-470.

Mattiazzi,A. and Kranias,E.G. (2014). The role of CaMKII regulation of phospholamban activity in heart disease. Front Pharmacol. 5, 5.

Meisel,S.R., Kutz,I., Dayan,K.I., Pauzner,H., Chetboun,I., Arbel,Y., and David,D. (1991). Effect of Iraqi missile war on incidence of acute myocardial infarction and sudden death in Israeli civilians. Lancet 338, 660-661.

Mery,P.F., Lohmann,S.M., Walter,U., and Fischmeister,R. (1991). Ca2+ current is regulated by cyclic GMP-dependent protein kinase in mammalian cardiac myocytes. Proc. Natl. Acad. Sci. U. S. A $88,1197-1201$.

Mirams,G.R., Davies,M.R., Cui,Y., Kohl,P., and Noble,D. (2012). Application of cardiac electrophysiology simulations to pro-arrhythmic safety testing. Br. J. Pharmacol. 167, 932-945.

Miyake,C.Y., Webster,G., Czosek,R.J., Kantoch,M.J., Dubin,A.M., Avasarala,K., and Atallah,J. (2013). Efficacy of implantable cardioverter defibrillators in young patients with catecholaminergic polymorphic ventricular tachycardia: success depends on substrate. Circ. Arrhythm. Electrophysiol. 6, 579-587.

Moore,E.N., PRESTON,J.B., and Moe,G.K. (1965). DURATIONS OF TRANSMEMBRANE ACTION POTENTIALS AND FUNCTIONAL REFRACTORY PERIODS OF CANINE FALSE TENDON AND VENTRICULAR MYOCARDIUM: COMPARISONS IN SINGLE FIBERS. Circ. Res. 17, 259-273.

Munroe,P.B. and Tinker,A. (2015). Genome-wide association studies and contribution to cardiovascular physiology. Physiol Genomics 47, 365-375.

Murphy,B.J., Rogers,J., Perdichizzi,A.P., Colvin,A.A., and Catterall,W.A. (1996). cAMPdependent phosphorylation of two sites in the alpha subunit of the cardiac sodium channel. J. Biol. Chem. 271, 28837-28843.

Myles,R.C., Wang,L., Kang,C., Bers,D.M., and Ripplinger,C.M. (2012). Local beta-adrenergic stimulation overcomes source-sink mismatch to generate focal arrhythmia. Circ. Res. 110, 14541464.

Nakayama,H., Bodi,I., Maillet,M., DeSantiago,J., Domeier,T.L., Mikoshiba,K., Lorenz,J.N., Blatter,L.A., Bers,D.M., and Molkentin,J.D. (2010). The IP3 receptor regulates cardiac hypertrophy in response to select stimuli. Circ. Res. 107, 659-666.

Ng,G.A., Brack,K.E., Patel,V.H., and Coote,J.H. (2007). Autonomic modulation of electrical restitution, alternans and ventricular fibrillation initiation in the isolated heart. Cardiovasc. Res. 73, 750-760.

Ng,G.A., Mantravadi,R., Walker,W.H., Ortin,W.G., Choi,B.R., de,G.W., and Salama,G. (2009). Sympathetic nerve stimulation produces spatial heterogeneities of action potential restitution. Heart Rhythm. 6, 696-706.

Nicolas,C.S., Park,K.H., El,H.A., Camonis,J., Kass,R.S., Escande,D., Merot,J., Loussouarn,G., 
Le,B.F., and Baro,I. (2008). IKs response to protein kinase A-dependent KCNQ1 phosphorylation requires direct interaction with microtubules. Cardiovasc. Res. 79, 427-435.

Nicoll,D.A., Ren,X., Ottolia,M., Phillips,M., Paredes,A.R., Abramson,J., and Philipson,K.D. (2007). What we know about the structure of NCX1 and how it relates to its function. Ann. N. Y. Acad. Sci. 1099, 1-6.

Niiyama,M., Tanaka,F., Nakajima,S., Itoh,T., Matsumoto,T., Kawakami,M., Naganuma,Y., Omama,S., Komatsu,T., Onoda,T., Sakata,K., Ichikawa,T., and Nakamura,M. (2014). Populationbased incidence of sudden cardiac and unexpected death before and after the 2011 earthquake and tsunami in Iwate, northeast Japan. J. Am. Heart Assoc. 3, e000798.

Nikolaev,V.O., Moshkov,A., Lyon,A.R., Miragoli,M., Novak,P., Paur,H., Lohse,M.J., Korchev,Y.E., Harding,S.E., and Gorelik,J. (2010). Beta2-adrenergic receptor redistribution in heart failure changes cAMP compartmentation. Science 327, 1653-1657.

Noble,D. (1984). The surprising heart: a review of recent progress in cardiac electrophysiology. J. Physiol (Lond) 353, 1-50.

Noble,D. (2002). Modelling the heart: insights, failures and progress. Bioessays 24, 1155-1163.

Nolasco,J.B. and Dahlen,R.W. (1968). A graphic method for the study of alternation in cardiac action potentials. J. Appl. Physiol 25, 191-196.

O'Hara,T., Virag,L., Varro,A., and Rudy,Y. (2011). Simulation of the undiseased human cardiac ventricular action potential: model formulation and experimental validation. PLoS. Comput. Biol. 7 , e1002061.

Ochi,R., Momose,Y., Oyama,K., and Giles,W.R. (2006). Sphingosine-1-phosphate effects on guinea pig atrial myocytes: Alterations in action potentials and $\mathrm{K}+$ currents. Cardiovasc. Res. 70, 88-96.

Odening,K.E. (2016). Another jigsaw piece in the complex picture of hormonal regulation of cardiac repolarization. Eur. Heart J. 37, 651-653.

Odening,K.E. and Koren,G. (2014). How do sex hormones modify arrhythmogenesis in long QT syndrome? Sex hormone effects on arrhythmogenic substrate and triggered activity. Heart Rhythm. $11,2107-2115$.

Opthof,T., Remme,C.A., Jorge,E., Noriega,F., Wiegerinck,R.F., Tasiam,A., Beekman,L., AlvarezGarcia,J., Munoz-Guijosa,C., Coronel,R., and Cinca,J. (2016). Cardiac activation-repolarization patterns and ion channel expression mapping in intact isolated normal human hearts. Heart Rhythm.

Oudit,G.Y., Kassiri,Z., Sah,R., Ramirez,R.J., Zobel,C., and Backx,P.H. (2001). The molecular physiology of the cardiac transient outward potassium current (I(to)) in normal and diseased myocardium. J. Mol. Cell Cardiol. 33, 851-872.

Pandit,S.V. (2010). T-wave alternans testing: can it predict arrhythmogenesis? Heart Rhythm. 7, 769-770.

Pauziene,N., Alaburda,P., Rysevaite-Kyguoliene,K., Pauza,A.G., Inokaitis,H., Masaityte,A., Rudokaite,G., Saburkina,I., Plisiene,J., and Pauza,D.H. (2016). Innervation of the rabbit cardiac ventricles. J. Anat. 228, 26-46. 
Peralta,E.G., Ashkenazi,A., Winslow,J.W., Ramachandran,J., and Capon,D.J. (1988). Differential regulation of PI hydrolysis and adenylyl cyclase by muscarinic receptor subtypes. Nature 334, 434437.

Peralta,E.G., Ashkenazi,A., Winslow,J.W., Smith,D.H., Ramachandran,J., and Capon,D.J. (1987). Distinct primary structures, ligand-binding properties and tissue-specific expression of four human muscarinic acetylcholine receptors. EMBO J. 6, 3923-3929.

Peters,N.S., Coromilas,J., Severs,N.J., and Wit,A.L. (1997). Disturbed connexin43 gap junction distribution correlates with the location of reentrant circuits in the epicardial border zone of healing canine infarcts that cause ventricular tachycardia. Circulation 95, 988-996.

Pieske,B., Beyermann,B., Breu,V., Loffler,B.M., Schlotthauer,K., Maier,L.S., Schmidt-Schweda,S., Just,H., and Hasenfuss,G. (1999). Functional effects of endothelin and regulation of endothelin receptors in isolated human nonfailing and failing myocardium. Circulation 99, 1802-1809.

Poole-Wilson,P.A., Swedberg,K., Cleland,J.G., Di Lenarda,A., Hanrath,P., Komajda,M., Lubsen,J., Lutiger,B., Metra,M., Remme,W.J., Torp-Pedersen,C., Scherhag,A., and Skene,A. (2003).

Comparison of carvedilol and metoprolol on clinical outcomes in patients with chronic heart failure in the Carvedilol Or Metoprolol European Trial (COMET): randomised controlled trial. Lancet 362, 7-13.

Priori,S.G., Napolitano,C., Tiso,N., Memmi,M., Vignati,G., Bloise,R., Sorrentino,V., V, and Danieli,G.A. (2001). Mutations in the Cardiac Ryanodine Receptor Gene (hRyR2) Underlie Catecholaminergic Polymorphic Ventricular Tachycardia. Circulation 103, 196-200.

Pueyo,E., Husti,Z., Hornyik,T., Baczko,I., Laguna,P., Varro,A., and Rodriguez,B. (2010). Mechanisms of ventricular rate adaptation as a predictor of arrhythmic risk. Am. J. Physiol Heart Circ. Physiol 298, H1577-H1587.

Pueyo,E., Malik,M., and Laguna,P. (2005). Beat-to-beat Adaptation of QT Interval to Heart Rate. Conf. Proc. IEEE Eng Med. Biol. Soc. 3, 2475-2478.

Pueyo,E., Orini,M., Rodriguez,J.F., and Taggart,P. (2016). Interactive effect of beta-adrenergic stimulation and mechanical stretch on low-frequency oscillations of ventricular action potential duration in humans. J. Mol. Cell Cardiol. 97, 93-105.

Pueyo,E., Smetana,P., Caminal,P., de Luna,A.B., Malik,M., and Laguna,P. (2004). Characterization of QT interval adaptation to RR interval changes and its use as a risk-stratifier of arrhythmic mortality in amiodarone-treated survivors of acute myocardial infarction. IEEE Trans. Biomed. Eng 51, 1511-1520.

Putzke,C., Wemhoner,K., Sachse,F.B., Rinne,S., Schlichthorl,G., Li,X.T., Jae,L., Eckhardt,I., Wischmeyer,E., Wulf,H., Preisig-Muller,R., Daut,J., and Decher,N. (2007). The acid-sensitive potassium channel TASK-1 in rat cardiac muscle. Cardiovasc. Res. 75, 59-68.

Quinn,K.V., Cui,Y., Giblin,J.P., Clapp,L.H., and Tinker,A. (2003). Do anionic phospholipids serve as cofactors or second messengers for the regulation of activity of cloned ATP-sensitive K+ channels? Circ. Res. 93, 646-655.

Quinn,K.V., Giblin,J.P., and Tinker,A. (2004). Multisite Phosphorylation Mechanism for Protein Kinase A Activation of the Smooth Muscle ATP-Sensitive K+ Channel. Circ. Res. 94, 1359-1366. 
Rajagopalan,V. and Gerdes,A.M. (2015). Role of thyroid hormones in ventricular remodeling. Curr. Heart Fail. Rep. 12, 141-149.

Regard,J.B., Sato,I.T., and Coughlin,S.R. (2008). Anatomical profiling of G protein-coupled receptor expression. Cell 135, 561-571.

Regitz-Zagrosek,V., Friedel,N., Heymann,A., Bauer,P., Neuss,M., Rolfs,A., Steffen,C., Hildebrandt,A., Hetzer,R., and Fleck,E. (1995). Regulation, chamber localization, and subtype distribution of angiotensin II receptors in human hearts. Circulation 91, 1461-1471.

Reppert,S.M. and Weaver,D.R. (2002). Coordination of circadian timing in mammals. Nature 418, 935-941.

Reuter,H. (1967). The dependence of slow inward current in Purkinje fibres on the extracellular calcium-concentration. J. Physiol 192, 479-492.

Roden,D.M., Balser,J.R., George,A.L., Jr., and Anderson,M.E. (2002). Cardiac ion channels. Annu. Rev. Physiol 64, 431-475.

Rodriguez,B., Carusi,A., Abi-Gerges,N., Ariga,R., Britton,O., Bub,G., Bueno-Orovio,A., Burton,R.A., Carapella,V., Cardone-Noott,L., Daniels,M.J., Davies,M.R., Dutta,S., Ghetti,A., Grau,V., Harmer,S., Kopljar,I., Lambiase,P., Lu,H.R., Lyon,A., Minchole,A., Muszkiewicz,A., Oster,J., Paci,M., Passini,E., Severi,S., Taggart,P., Tinker,A., Valentin,J.P., Varro,A., Wallman,M., and Zhou,X. (2015). Human-based approaches to pharmacology and cardiology: an interdisciplinary and intersectorial workshop. Europace.

Rodriguez,I., Kilborn,M.J., Liu,X.K., Pezzullo,J.C., and Woosley,R.L. (2001). Drug-induced QT prolongation in women during the menstrual cycle. JAMA 285, 1322-1326.

Sadrieh,A., Domanski,L., Pitt-Francis,J., Mann,S.A., Hodkinson,E.C., Ng,C.A., Perry,M.D., Taylor,J.A., Gavaghan,D., Subbiah,R.N., Vandenberg,J.I., and Hill,A.P. (2014). Multiscale cardiac modelling reveals the origins of notched $\mathrm{T}$ waves in long QT syndrome type 2. Nat. Commun. 5, 5069 .

Saint,D.A. (2008). The cardiac persistent sodium current: an appealing therapeutic target? Br. J. Pharmacol. 153, 1133-1142.

Sanguinetti,M.C., Curran,M.E., Zou,A., Shen,J., Spector,P.S., Atkinson,D.L., and Keating,M.T. (1996). Coassembly of K(V)LQT1 and minK (IsK) proteins to form cardiac I(Ks) potassium channel. Nature 384, 80-83.

Sanguinetti,M.C. and Jurkiewicz,N.K. (1990). Two components of cardiac delayed rectifier K+ current. Differential sensitivity to block by class III antiarrhythmic agents. J. Gen. Physiol. 96, 195215.

Sanguinetti,M.C., Jurkiewicz,N.K., Scott,A., and Siegl,P.K. (1991). Isoproterenol antagonizes prolongation of refractory period by the class III antiarrhythmic agent E-4031 in guinea pig myocytes. Mechanism of action. Circ. Res. 68, 77-84.

Saucerman,J.J., Brunton,L.L., Michailova,A.P., and McCulloch,A.D. (2003). Modeling betaadrenergic control of cardiac myocyte contractility in silico. J. Biol. Chem. 278, 47997-48003.

Saucerman,J.J. and McCulloch,A.D. (2004). Mechanistic systems models of cell signaling networks: a case study of myocyte adrenergic regulation. Prog. Biophys. Mol. Biol. 85, 261-278. 
Schmitt,N., Grunnet,M., and Olesen,S.P. (2014). Cardiac potassium channel subtypes: new roles in repolarization and arrhythmia. Physiol Rev. 94, 609-653.

Schwartz,P.J., Priori,S.G., Spazzolini,C., Moss,A.J., Vincent,G.M., Napolitano,C., Denjoy,I., Guicheney,P., Breithardt,G., Keating,M.T., Towbin,J.A., Beggs,A.H., Brink,P., Wilde,A.A., Toivonen,L., Zareba,W., Robinson,J.L., Timothy,K.W., Corfield,V., Wattanasirichaigoon,D., Corbett,C., Haverkamp,W., Schulze-Bahr,E., Lehmann,M.H., Schwartz,K., Coumel,P., and Bloise,R. (2001). Genotype-phenotype correlation in the long-QT syndrome: gene-specific triggers for life-threatening arrhythmias. Circulation 103, 89-95.

Sears,C.E., Bryant,S.M., Ashley,E.A., Lygate,C.A., Rakovic,S., Wallis,H.L., Neubauer,S., Terrar,D.A., and Casadei,B. (2003). Cardiac neuronal nitric oxide synthase isoform regulates myocardial contraction and calcium handling. Circ. Res. 92, e52-e59.

Sessa,W.C. (1994). The nitric oxide synthase family of proteins. J. Vasc. Res. 31, 131-143.

Sessa,W.C., Harrison,J.K., Barber,C.M., Zeng,D., Durieux,M.E., D'Angelo,D.D., Lynch,K.R., and Peach,M.J. (1992). Molecular cloning and expression of a cDNA encoding endothelial cell nitric oxide synthase. J. Biol. Chem. 267, 15274-15276.

Shan,J., Kushnir,A., Betzenhauser,M.J., Reiken,S., Li,J., Lehnart,S.E., Lindegger,N., Mongillo,M., Mohler,P.J., and Marks,A.R. (2010). Phosphorylation of the ryanodine receptor mediates the cardiac fight or flight response in mice. J. Clin. Invest 120, 4388-4398.

Shattock,M.J. and Tipton,M.J. (2012). 'Autonomic conflict': a different way to die during cold water immersion? J. Physiol 590, 3219-3230.

Shedd,O.L., Sears,S.F., Jr., Harvill,J.L., Arshad,A., Conti,J.B., Steinberg,J.S., and Curtis,A.B. (2004). The World Trade Center attack: increased frequency of defibrillator shocks for ventricular arrhythmias in patients living remotely from New York City. J. Am. Coll. Cardiol. 44, 1265-1267.

Shenoy,S.K., Drake,M.T., Nelson,C.D., Houtz,D.A., Xiao,K., Madabushi,S., Reiter,E., Premont,R.T., Lichtarge,O., and Lefkowitz,R.J. (2006). beta-arrestin-dependent, G proteinindependent ERK1/2 activation by the beta2 adrenergic receptor. J. Biol. Chem. 281, 1261-1273.

Shimoni,Y. (1999). Protein kinase $\mathrm{C}$ regulation of $\mathrm{K}+$ currents in rat ventricular myocytes and its modification by hormonal status. J. Physiol 520 Pt 2, 439-449.

Shimoni,Y. and Banno,H. (1993). Alpha-adrenergic modulation of transient outward current in hyperthyroid rabbit myocytes. Am. J. Physiol 264, H74-H77.

Shukla,A.K., Westfield,G.H., Xiao,K., Reis,R.I., Huang,L.Y., Tripathi-Shukla,P., Qian,J., Li,S., Blanc,A., Oleskie,A.N., Dosey,A.M., Su,M., Liang,C.R., Gu,L.L., Shan,J.M., Chen,X., Hanna,R., Choi,M., Yao,X.J., Klink,B.U., Kahsai,A.W., Sidhu,S.S., Koide,S., Penczek,P.A., Kossiakoff,A.A., Woods, V.L., Jr., Kobilka,B.K., Skiniotis,G., and Lefkowitz,R.J. (2014). Visualization of arrestin recruitment by a G-protein-coupled receptor. Nature 512, 218-222.

Shyng,S. and Nichols,C.G. (1998). Membrane Phospholipid Control of Nucleotide Sensitivity of $\mathrm{K}_{\text {ATP }}$ Channels. Science 282, 1138-1141.

Silva,J. and Rudy,Y. (2005). Subunit interaction determines IKs participation in cardiac repolarization and repolarization reserve. Circulation 112, 1384-1391.

Simon,D.I., Mullins,M.E., Jia,L., Gaston,B., Singel,D.J., and Stamler,J.S. (1996). Polynitrosylated 
proteins: characterization, bioactivity, and functional consequences. Proc. Natl. Acad. Sci. U. S. A 93, 4736-4741.

Simon,J.N., Duglan,D., Casadei,B., and Carnicer,R. (2014). Nitric oxide synthase regulation of cardiac excitation-contraction coupling in health and disease. J. Mol. Cell Cardiol. 73, 80-91.

Sipido,K.R., Callewaert,G., and Carmeliet,E. (1995). Inhibition and rapid recovery of Ca2+ current during $\mathrm{Ca} 2+$ release from sarcoplasmic reticulum in guinea pig ventricular myocytes. Circ. Res. 76, 102-109.

Sosunov,E.A., Obreztchikova,M.N., Anyukhovsky,E.P., Moise,N.S., Danilo,P., Jr., Robinson,R.B., and Rosen,M.R. (2004). Mechanisms of alpha-adrenergic potentiation of ventricular arrhythmias in dogs with inherited arrhythmic sudden death. Cardiovasc. Res. 61, 715-723.

Steinberg,J.S., Arshad,A., Kowalski,M., Kukar,A., Suma,V., Vloka,M., Ehlert,F., Herweg,B., Donnelly,J., Philip,J., Reed,G., and Rozanski,A. (2004). Increased incidence of life-threatening ventricular arrhythmias in implantable defibrillator patients after the World Trade Center attack. J. Am. Coll. Cardiol. 44, 1261-1264.

Stopper,M., Joska,T., Burg,M.M., Batsford,W.P., McPherson,C.A., Jain,D., and Lampert,R. (2007). Electrophysiologic characteristics of anger-triggered arrhythmias. Heart Rhythm. 4, 268-273.

Sugden,P.H. and Clerk,A. (1998). Cellular mechanisms of cardiac hypertrophy. J. Mol. Med. (Berl) 76, 725-746.

Taggart,P., Sutton,P., Chalabi,Z., Boyett,M.R., Simon,R., Elliott,D., and Gill,J.S. (2003). Effect of adrenergic stimulation on action potential duration restitution in humans. Circulation 107, 285-289.

Tanabe,Y., Inagaki,M., Kurita,T., Nagaya,N., Taguchi,A., Suyama,K., Aihara,N., Kamakura,S., Sunagawa,K., Nakamura,K., Ohe,T., Towbin,J.A., Priori,S.G., and Shimizu,W. (2001).

Sympathetic stimulation produces a greater increase in both transmural and spatial dispersion of repolarization in LQT1 than LQT2 forms of congenital long QT syndrome. J. Am. Coll. Cardiol. 37, 911-919.

Terrenoire,C., Houslay,M.D., Baillie,G.S., and Kass,R.S. (2009). The cardiac IKs potassium channel macromolecular complex includes the phosphodiesterase PDE4D3. J. Biol. Chem. 284, 9140-9146.

Tinker,A., Aziz,Q., and Thomas,A. (2014). The role of ATP-sensitive potassium channels in cellular function and protection in the cardiovascular system. Br. J. Pharmacol. 171, 12-23.

Tinker,A., Finlay,M., Nobles,M., and Opel,A. (2016). The contribution of pathways initiated via the $\mathrm{G}_{\mathrm{q} \mid 11} \mathrm{G}-$ protein family to atrial fibrillation. Pharmacol. Res. 105, 54-61.

Toivonen,L., Helenius,K., and Viitasalo,M. (1997). Electrocardiographic repolarization during stress from awakening on alarm call. J. Am. Coll. Cardiol. 30, 774-779.

Trudeau,M.C., Warmke,J.W., Ganetzky,B., and Robertson,G.A. (1995). HERG, a human inward rectifier in the voltage-gated potassium channel family. Science 269, 92-95.

Tsien,R.W., Bean,B.P., Hess,P., Lansman,J.B., Nilius,B., and Nowycky,M.C. (1986). Mechanisms of calcium channel modulation by beta-adrenergic agents and dihydropyridine calcium agonists. J. Mol. Cell Cardiol. 18, 691-710. 
van der Heyden,M.A., Wijnhoven,T.J., and Opthof,T. (2006). Molecular aspects of adrenergic modulation of the transient outward current. Cardiovasc. Res. 71, 430-442.

Vargas-Uricoechea,H. and Sierra-Torres,C.H. (2014). Thyroid hormones and the heart. Horm. Mol. Biol. Clin. Investig. 18, 15-26.

Verrier,R.L. and Lown,B. (1984). Behavioral stress and cardiac arrhythmias. Annu. Rev. Physiol 46, 155-176.

Vijayakumar,R., Silva,J.N., Desouza,K.A., Abraham,R.L., Strom,M., Sacher,F., Van Hare,G.F., Haissaguerre,M., Roden,D.M., and Rudy,Y. (2014). Electrophysiologic substrate in congenital Long QT syndrome: noninvasive mapping with electrocardiographic imaging (ECGI). Circulation 130, 1936-1943.

Vincent,G.M., Schwartz,P.J., Denjoy,I., Swan,H., Bithell,C., Spazzolini,C., Crotti,L., Piippo,K., Lupoglazoff,J.M., Villain,E., Priori,S.G., Napolitano,C., and Zhang,L. (2009). High efficacy of beta-blockers in long-QT syndrome type 1: contribution of noncompliance and QT-prolonging drugs to the occurrence of beta-blocker treatment "failures". Circulation 119, 215-221.

Waagstein,F., Bristow,M.R., Swedberg,K., Camerini,F., Fowler,M.B., Silver,M.A., Gilbert,E.M., Johnson,M.R., Goss,F.G., and Hjalmarson,A. (1993). Beneficial effects of metoprolol in idiopathic dilated cardiomyopathy. Metoprolol in Dilated Cardiomyopathy (MDC) Trial Study Group. Lancet 342, 1441-1446.

Wang,W., Zhu,W., Wang,S., Yang,D., Crow,M.T., Xiao,R.P., and Cheng,H. (2004a). Sustained beta 1 -adrenergic stimulation modulates cardiac contractility by $\mathrm{Ca} 2+/$ calmodulin kinase signaling pathway. Circ. Res. 95, 798-806.

Wang,Z., Shi,H., and Wang,H. (2004b). Functional M3 muscarinic acetylcholine receptors in mammalian hearts. Br. J. Pharmacol. 142, 395-408.

Wehrens,X.H., Lehnart,S.E., Huang,F., Vest,J.A., Reiken,S.R., Mohler,P.J., Sun,J., Guatimosim,S., Song,L.S., Rosemblit,N., D'Armiento,J.M., Napolitano,C., Memmi,M., Priori,S.G., Lederer,W.J., and Marks,A.R. (2003). FKBP12.6 deficiency and defective calcium release channel (ryanodine receptor) function linked to exercise-induced sudden cardiac death. Cell 113, 829-840.

Wehrens,X.H., Lehnart,S.E., Reiken,S., Vest,J.A., Wronska,A., and Marks,A.R. (2006). Ryanodine receptor/calcium release channel PKA phosphorylation: a critical mediator of heart failure progression. Proc. Natl. Acad. Sci. U. S. A 103, 511-518.

Weiss,J.N., Qu,Z., Chen,P.S., Lin,S.F., Karagueuzian,H.S., Hayashi,H., Garfinkel,A., and Karma,A. (2005). The dynamics of cardiac fibrillation. Circulation 112, 1232-1240.

Westenbroek,R.E., Bischoff,S., Fu,Y., Maier,S.K., Catterall,W.A., and Scheuer,T. (2013). Localization of sodium channel subtypes in mouse ventricular myocytes using quantitative immunocytochemistry. J. Mol. Cell Cardiol. 64C, 69-78.

Wettwer,E., Amos,G.J., Posival,H., and Ravens,U. (1994). Transient outward current in human ventricular myocytes of subepicardial and subendocardial origin. Circ. Res. 75, 473-482.

Wilbert-Lampen,U., Leistner,D., Greven,S., Pohl,T., Sper,S., Volker,C., Guthlin,D., Plasse,A., Knez,A., Kuchenhoff,H., and Steinbeck,G. (2008). Cardiovascular events during World Cup soccer. N. Engl. J. Med. 358, 475-483. 
Williams,J.C., Armesilla,A.L., Mohamed,T.M., Hagarty,C.L., McIntyre,F.H., Schomburg,S., Zaki,A.O., Oceandy,D., Cartwright,E.J., Buch,M.H., Emerson,M., and Neyses,L. (2006). The sarcolemmal calcium pump, alpha-1 syntrophin, and neuronal nitric-oxide synthase are parts of a macromolecular protein complex. J. Biol. Chem. 281, 23341-23348.

Willich,S.N., Levy,D., Rocco,M.B., Tofler,G.H., Stone,P.H., and Muller,J.E. (1987). Circadian variation in the incidence of sudden cardiac death in the Framingham Heart Study population. Am. J. Cardiol. 60, 801-806.

Wisler,J.W., DeWire,S.M., Whalen,E.J., Violin,J.D., Drake,M.T., Ahn,S., Shenoy,S.K., and Lefkowitz,R.J. (2007). A unique mechanism of beta-blocker action: carvedilol stimulates betaarrestin signaling. Proc. Natl. Acad. Sci. U. S. A 104, 16657-16662.

Wisler,J.W., Xiao,K., Thomsen,A.R., and Lefkowitz,R.J. (2014). Recent developments in biased agonism. Curr. Opin. Cell Biol. 27, 18-24.

Xenopoulos,N.P. and Applegate,R.J. (1994). The effect of vagal stimulation on left ventricular systolic and diastolic performance. Am. J. Physiol 266, H2167-H2173.

Xiao,R.P., Zhang,S.J., Chakir,K., Avdonin,P., Zhu,W., Bond,R.A., Balke,C.W., Lakatta,E.G., and Cheng,H. (2003). Enhanced G(i) signaling selectively negates beta2-adrenergic receptor (AR)--but not beta1-AR-mediated positive inotropic effect in myocytes from failing rat hearts. Circulation 108, 1633-1639.

Xiao,R.P., Zhu,W., Zheng,M., Cao,C., Zhang,Y., Lakatta,E.G., and Han,Q. (2006). Subtypespecific alpha1- and beta-adrenoceptor signaling in the heart. Trends Pharmacol. Sci. 27, 330-337.

Xiao,R.-P., Avdonin,P., Zhou,Y.-Y., Cheng,H., Akhter,S.A., Eschenhagen,T., Lefkowitz,R.J., Koch,W.J., and Lakatta,E.G. (1999). Coupling of $\beta_{2}$-adrenoceptor to $\mathrm{G}_{\mathrm{i}}$ proteins and its physiological relevance in murine cardiac mycocytes. Circulation Research 84, 43-52.

Xie,Y., Ding,W.G., and Matsuura,H. (2015). Ca2+/calmodulin potentiates I Ks in sinoatrial node cells by activating Ca2+/calmodulin-dependent protein kinase II. Pflugers Arch. 467, 241-251.

Xie,Y., Grandi,E., Puglisi,J.L., Sato,D., and Bers,D.M. (2013). beta-adrenergic stimulation activates early afterdepolarizations transiently via kinetic mismatch of PKA targets. J. Mol. Cell Cardiol. 58, 153-161.

Xu,K.Y., Huso,D.L., Dawson,T.M., Bredt,D.S., and Becker,L.C. (1999). Nitric oxide synthase in cardiac sarcoplasmic reticulum. Proc. Natl. Acad. Sci. U. S. A 96, 657-662.

Yoshioka,K., Gao,D.W., Chin,M., Stillson,C., Penades,E., Lesh,M., O'Connell,W., and Dae,M. (2000). Heterogeneous sympathetic innervation influences local myocardial repolarization in normally perfused rabbit hearts. Circulation 101, 1060-1066.

Zannad,F., De Ferrari,G.M., Tuinenburg,A.E., Wright,D., Brugada,J., Butter,C., Klein,H., Stolen,C., Meyer,S., Stein,K.M., Ramuzat,A., Schubert,B., Daum,D., Neuzil,P., Botman,C., Castel,M.A., D'Onofrio,A., Solomon,S.D., Wold,N., and Ruble,S.B. (2015). Chronic vagal stimulation for the treatment of low ejection fraction heart failure: results of the NEural Cardiac TherApy foR Heart Failure (NECTAR-HF) randomized controlled trial. Eur. Heart J. 36, 425-433.

Zaritsky,J.J., Redell,J.B., Tempel,B.L., and Schwarz,T.L. (2001). The consequences of disrupting cardiac inwardly rectifying $\mathrm{K}(+)$ current $(\mathrm{I}(\mathrm{K} 1))$ as revealed by the targeted deletion of the murine 
Kir2.1 and Kir2.2 genes. J. Physiol 533, 697-710.

Zingman,L.V., Hodgson,D.M., Bast,P.H., Kane,G.C., Perez-Terzic,C., Gumina,R.J., Pucar,D., Bienengraeber,M., Dzeja,P.P., Miki,T., Seino,S., Alekseev,A.E., and Terzic,A. (2002). Kir6.2 is required for adaptation to stress. Proc. Natl. Acad. Sci. U. S. A 99, 13278-13283.

Ziv,O., Morales,E., Song,Y.K., Peng,X., Odening,K.E., Buxton,A.E., Karma,A., Koren,G., and Choi,B.R. (2009). Origin of complex behaviour of spatially discordant alternans in a transgenic rabbit model of type 2 long QT syndrome. J. Physiol 587, 4661-4680. 


\begin{tabular}{|c|c|c|c|c|c|c|c|}
\hline Current & $\begin{array}{l}\text { Molecular } \\
\text { Composition }\end{array}$ & $\begin{array}{l}\beta \text {-adrenergic } \\
\text { regulation }\end{array}$ & $\begin{array}{l}\alpha 1 \text {-adrenergic } \\
\text { regulation }\end{array}$ & $\begin{array}{l}\text { Muscarinic } \\
\text { receptor regulation }\end{array}$ & $\begin{array}{l}\text { Nitric Oxide } \\
\text { signalling }\end{array}$ & CamKII signalling & Other \\
\hline$\overline{\mathbf{I}_{\mathrm{Na}}}$ & SCN5A $+\beta$-subunits & $\begin{array}{l}\text { Increases current } \\
\text { and channel } \\
\text { translocation }\end{array}$ & Not clear & Not clear & Not clear & Not clear & $\begin{array}{l}\mathrm{Ca}^{2+} \text { is inhibitory } \\
\text { probably by direct } \\
\text { pore block }\end{array}$ \\
\hline $\begin{array}{l}\text { L-type calcium } \\
\left.\text { current ( } \mathbf{I}_{\mathrm{CaL}}\right)\end{array}$ & $\begin{array}{l}\text { Cav1.2 with } \alpha_{2} \delta, \beta \text { and } \\
\gamma \text { subunits }\end{array}$ & $\begin{array}{l}\text { Increased via PKA } \\
\text { phosphorylation of } \\
\text { Cav1.2 }\end{array}$ & Not clear & $\begin{array}{l}\text { M2 (and A1) } \\
\text { antagonise but only } \\
\text { with } \beta \text {-adrenergic } \\
\text { activation }\end{array}$ & $\begin{array}{l}\text { Inhibitory via PKG } \\
\text { and direct channel } \\
\text { nitrosylation }\end{array}$ & $\begin{array}{l}\text { Increases via direct } \\
\text { CamKII } \\
\text { phosphorylation of } \\
\text { Cav1.2. Responsible } \\
\text { for } \mathrm{Ca}^{2+} \text { dependent } \\
\text { facilitation }\end{array}$ & $\begin{array}{l}\text { High concentrations } \\
\text { of } \mathrm{Ca}^{2+} \text { such as } \\
\text { occur on SR release } \\
\text { result in channel } \\
\text { inactivation }\end{array}$ \\
\hline $\mathbf{I}_{\mathbf{t o}_{\mathrm{o}}}$ & Kv4.2\4.3\KChiP & Not clear & Reduced & Not clear & Reduced & Not clear & $\begin{array}{l}\text { Reduced by } \\
\text { activation of } \\
\text { angiotensin II } \\
\text { receptor }\end{array}$ \\
\hline $\mathbf{I}_{\mathrm{Kr}}$ & KCNH2\KCNE2(?) & Not clear & Not clear & Not clear & Not clear & Not clear & $\begin{array}{l}\text { Augmented by } \\
\text { activation of } \\
\text { angiotensin II } \\
\text { receptor }\end{array}$ \\
\hline $\mathbf{I}_{\mathrm{Ks}}$ & KCNQ1\KCNE1 & $\begin{array}{l}\text { Increased via PKA } \\
\text { phosphorylation of } \\
\text { KCNQ1 }\end{array}$ & Not clear (see other) & Not clear (see other) & $\begin{array}{l}\text { Increased through } \\
\text { direct channel } \\
\text { nitrosylation }\end{array}$ & Not clear & $\begin{array}{l}\text { Angiotensin II and } \\
\text { other } \mathrm{G}_{\mathrm{q} \backslash 11} \text { coupled } \\
\text { receptors have been } \\
\text { described to inhibit } \\
\text { the current. Channel } \\
\text { activity strongly } \\
\text { dependent on PIP } \\
\text { dep. }\end{array}$ \\
\hline $\mathbf{I}_{\text {KATP }}$ & Kir6.2\SUR2A & $\begin{array}{l}\text { Perhaps increased. } \\
\text { Physiological } \\
\text { significance unclear. }\end{array}$ & Not clear & Not clear & Not clear & Not clear & $\begin{array}{l}\text { Inhibited by } \mathrm{PIP}_{2} \\
\text { depletion via } \mathrm{G}_{\mathrm{q} \mid 11} \\
\text { coupled receptor } \\
\text { activation. } \\
\text { Significance } \\
\text { unclear. } \\
\end{array}$ \\
\hline $\mathbf{I}_{\mathrm{K} 1}$ & Kir2.1 & Not clear & Not clear & Not clear & Not clear & No clear & $\begin{array}{l}\text { No clear consensus } \\
\text { on significant } \\
\text { regulation }\end{array}$ \\
\hline $\begin{array}{l}\text { Sodium-calcium } \\
\text { exchanger }\end{array}$ & NCX1 & None & None & None & None & None & $\begin{array}{l}\text { No significant } \\
\text { regulation }\end{array}$ \\
\hline
\end{tabular}



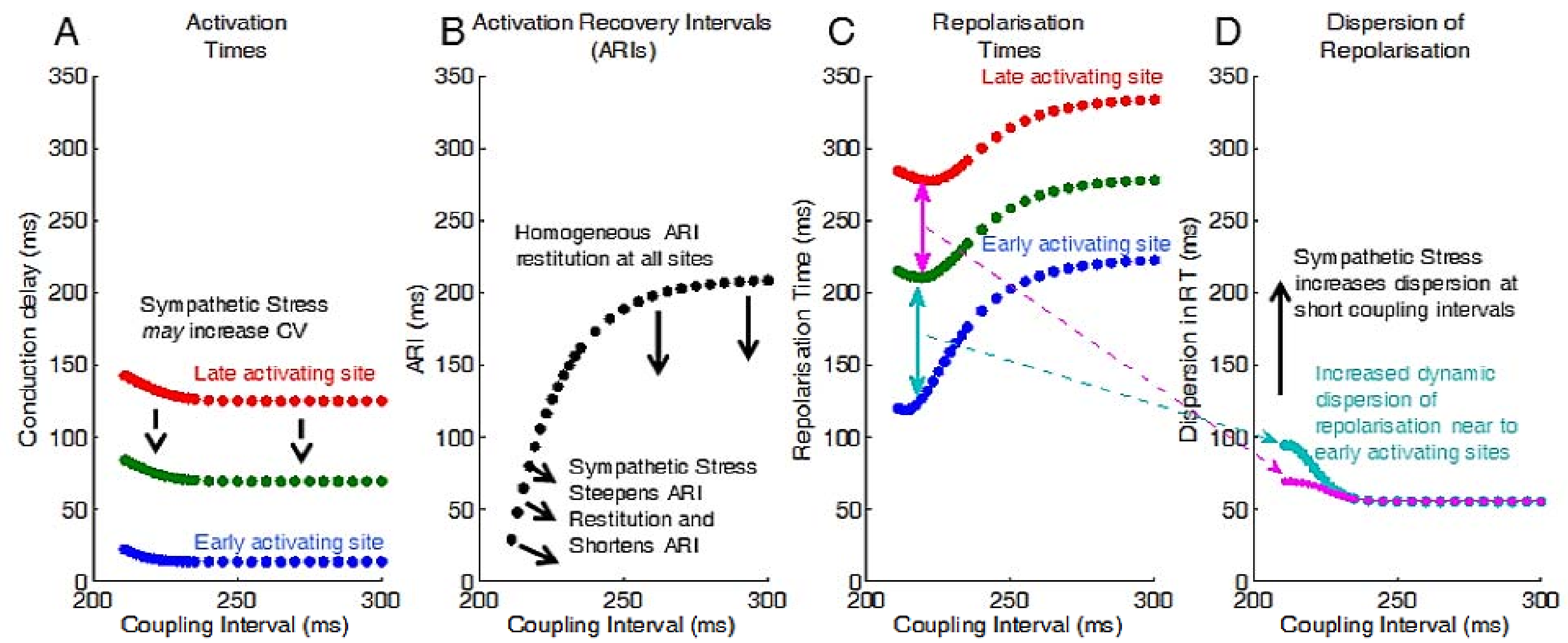


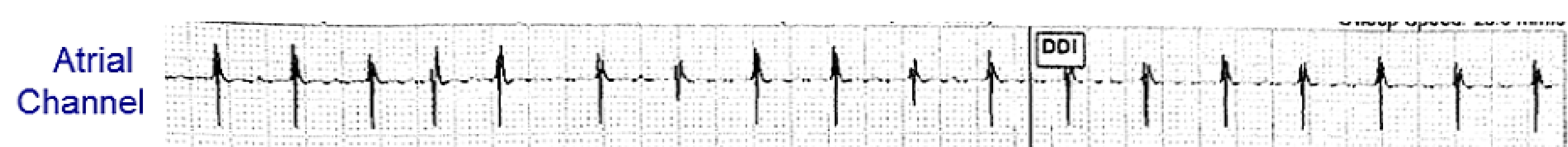

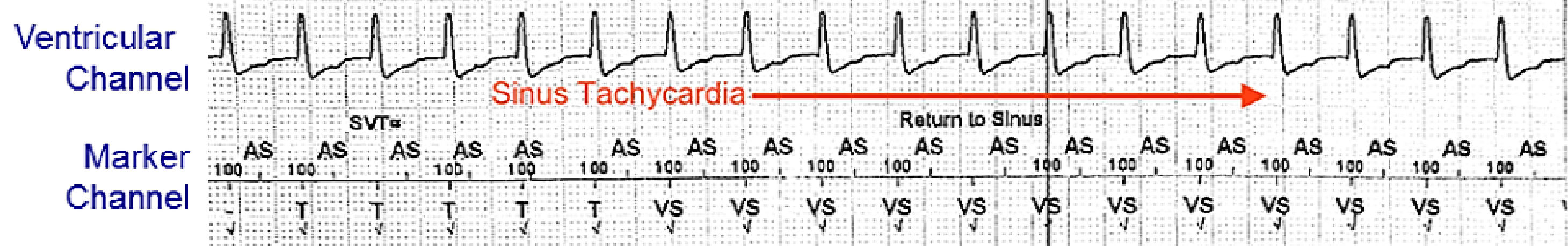

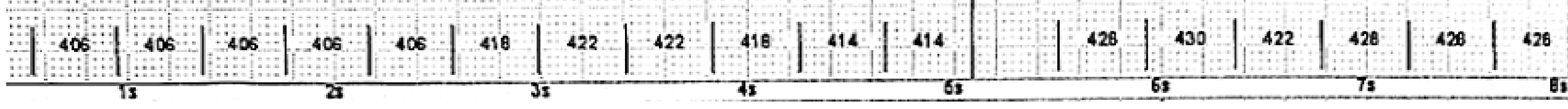

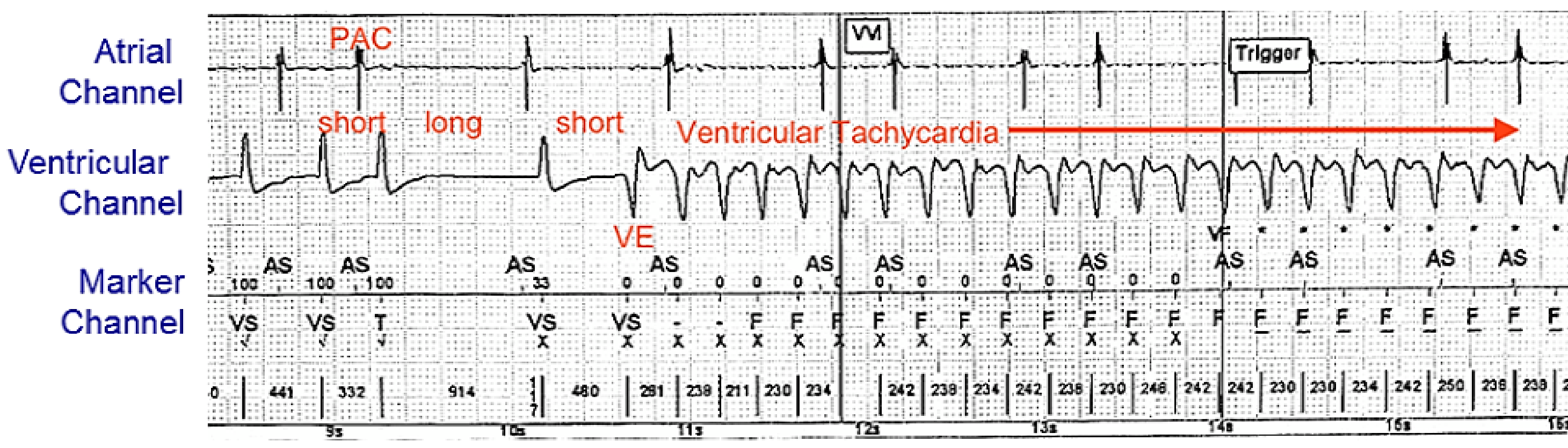

